地質学雑誌 第 114 巻 第 12 号 $632-647$ ページ, 2008 年 12 月

Jour. Geol. Soc. Japan, Vol. 114, No. 12, p. 632-647, December 2008

\title{
各種光学高分解能衛星画像による地質災害の判読ー判読特性の視点から見た 各種画像の比較検証一
}

Interpretation of geological hazard using high-resolution optical satellite imagery: Comparison of interpretation characteristics of satellite images

小荒井 衛*广 佐藤 浩* 宇根 寛* 天野一男”

Mamoru Koarai**, Hiroshi P. Sato*, Hiroshi Une* and Kazuo Amano*

2007 年 12 月 3 日受付.

2008 年 10 月 20 日受理.

国土地理院地理地殼活動研究センター

Geography and Crustal Dynamics Research Center, Geographical Survey Institute, 1 Kitasato, Tsukuba 305-0811, Japan 茨城大学理工学研究科

Graduate School of Science and Engineering, Ibaraki University, 2-1-1, Bunkyo, Mito 3108512, Japan

Corresponding author; M. Koarai, koarai@gsi.go.jp

\begin{abstract}
We analyzed large-scale geological hazards in the case of the Northern Pakistan Earthquake, the Middle Java Earthquake and the Leyte landslide, using optical high-resolution satellite imagery such as QuickBird, IKONOS, ALOS PRISM and SPOT5. The characteristics of satellite images were compared to those of disasters on the interpretation cards. It is possible to recognize large collapses using $\mathbf{2 . 5}$ m-resolution satellite images; however $1 \mathrm{~m}$-resolution satellite images are necessary for small-scale collapses and cracks. For the recognition of building damages in the urban area, $1 \mathrm{~m}$-resolution stereo images are necessary; however it is impossible by 1 m-resolution mono image. For surface earthquake faults, it is useful to combine the recognition of building heavy damaged area using $1 \mathrm{~m}$-resolution satellite image, and the identification of cliff landforms using 2.5 m-resolution stereo images. In order to understand hazard conditions, it is important for satellite imagery to be not only of high resolution but also stereoscopic.
\end{abstract}

We proposed a method for recognition of large-scale geological hazards using optical high-resolution satellite imagery.

Key words: high-resolution satellite imagery, interpretation characteristics, disaster monitoring, IKONOS, QuickBird, SPOT5, ALOS PRISM, the Northern Pakistan Earthquake, the Middle Java Earthquake, the Leyte landslide
は じめに

1999 年 9 月に $1 \mathrm{~m}$ 解像度の米国商用高分解能衛星 IKONOS の打ち上げが成功し, 名実共に高分解能衛星時代が 到来した。分解能 $1 \mathrm{~m}$ クラスの精度の高分解能衛星画像を 使うと, 分解能が $10 \mathrm{~m}$ よりも粗い中分解能衛星画像と同様 に画像の数值処理等による事象の指標化ができるほか, 航空 機により撮影された空中写真と同様に肉眼判読による情報抽 出も可能である. 特に災害状況を把握する場合, 肉眼判読能 力を最大限に活用して短時間に多様な災害現象を抽出できる ため, 災害初期の事態把握や海外での大災害時の実態把握に 際して有効な活用が期待される.

日本国内ではこれまで災害が起きると，国土地理院や各民 間航測会社等が災害直後の空中写真撮影を行い公開してきた (2004 年新潟県中越地震, 2007 年能登半島地震, 2007 年新潟 県中越沖地震など)。これら空中写真を使用すると，災害状 況の把握や地表変動現象の把握等を容易に行うことが出来 る。一方，開発途上国など外国での災害の場合，災害直後に 航空機による空中写真撮影が容易でないため, 高分解能衛星 画像による状況の把握に頼らざるを得ない。最近では, いく つかの国にもわたるような非常に大規模な災害が発生した際 には，被災地を撮影した様々な高分解能衛星画像が web 上
で公開されている.この傾向は, Google Earth 公開後に発 生した 2005 年パキスタン北部地震以降の世界的規模の大災 害ではっきりしてきた. このような状況の変化により, 被災 地に実際調査に入らなくても現地の災害状況の概要を容易に 知ることが出来るようになつた. 具体的にいくつかの報告が されている（例えば, 佐藤ほか, 2005 など）䀦 1)。国内の事例 としては，衛星画像を使った災害状況把握の研究例として, 向山 (2004,2006) などがある.

本稿では, 2005 年 10 月 8 日に発生したパキスタン北部 地震, 2006 年 5 月 27 日に発生したジャワ島中部地震, 2006 年 2 月 17 日に発生したレイテ島地すべりの海外で発 生した 3 つの大規模地質災害について, web 上で公開されて いるものも含めて光学系高分解能衛星画像を活用し, 被害状 況の把握とその地形学的な視点からの特性把握を試みた結果 を報告する、また，筆者らがこれまでに各衛星画像を大縮尺 空間デー夕の地物判読の視点から取りまとめた結果 (小荒井 ほか, 2005,2008a など）を参考にしながら, 各種光学系高分 解能衛星画像の災害判読特性を判読カードに整理しカタログ 化を進め, 災害判読特性を比較検証した結果を報告する.こ

\footnotetext{
畔 1) 佐藤 浩・宇根 寛・小荒井 衛, 2005, パキスタン北部地震に対する イコノス画像の判読と解釈. http://cais.gsi.go.jp/Research/geoinfo/ ikonos.pdf をあわせて参照のこと.
} 
第 1 表. 光学系高分解能衛星画像の種類.（(財）リモート・センシング技術センター（RESTEC）の HP から作成: 一部 RESTEC 職員 からの私信による)。サブサイクルは, 同一場所の撮影間隔

\begin{tabular}{|c|c|c|c|c|c|c|c|}
\hline \multicolumn{2}{|r|}{ 衛星センサー名 } & 分解能 & 観測幅 & 回帰日数 & $\begin{array}{c}\text { サブサイ } \\
\text { クル }\end{array}$ & 衛星高度 & 打ち上げ年月 \\
\hline \multirow{2}{*}{$\begin{array}{l}\text { Quick Bird } \\
\text { USA }\end{array}$} & パンクロマティツク & $0.61 \mathrm{~m}$ & \multirow{2}{*}{$16.5 \mathrm{~km}$} & \multirow{2}{*}{ 不明 } & \multirow{2}{*}{$\begin{array}{l}5 \sim 6 \text { 日 }(25 \\
\text { 度以内) }\end{array}$} & \multirow{2}{*}{$450 \mathrm{~km}$} & \multirow{2}{*}{2001 年 10 月 } \\
\hline & マルチスペクトラル (4バンド) & $2.44 m$ & & & & & \\
\hline \multirow{2}{*}{$\begin{array}{l}\text { IKONOS } \\
\text { USA }\end{array}$} & パンクロマティック & $1.0 \mathrm{~m}$ & \multirow{2}{*}{$11 \mathrm{~km}$} & \multirow{2}{*}{$\begin{array}{l}11 \text { 日 }(10 \\
\text { 度以内) }\end{array}$} & \multirow{2}{*}{$3 \sim 5$ 日 } & \multirow{2}{*}{$680 \mathrm{~km}$} & \multirow{2}{*}{1999 年 9 月 } \\
\hline & マルチスペクトラル (4 バンド) & $4.0 \mathrm{~m}$ & & & & & \\
\hline $\begin{array}{l}\text { EROS-AI } \\
\text { イスラエル }\end{array}$ & パンクロマティック & $1.8 \mathrm{~m}$ & $12.5 \mathrm{~km}$ & 7 日 & 2〜3 日 & $480 \mathrm{~km}$ & 2000 年 12 月 \\
\hline \multirow{2}{*}{$\begin{array}{l}\text { ALOS } \\
\text { 日本 }\end{array}$} & PRISM(パンクロマティック) & $2.5 \mathrm{~m}$ & $35 \mathrm{or} 70 \mathrm{~km}$ & \multirow{2}{*}{46 日 } & 46 日 & \multirow{2}{*}{$692 \mathrm{~km}$} & \multirow{2}{*}{2006 年 1 月 } \\
\hline & AVNIR2 (4 バンド) & $10 \mathrm{~m}$ & $70 \mathrm{~km}$ & & 2日 & & \\
\hline \multirow{2}{*}{$\begin{array}{l}\text { SPOT5 } \\
\text { フランス }\end{array}$} & HRG-P(パンクロマティック) & $50 \mathrm{o} 2.5 \mathrm{~m}$ & \multirow{2}{*}{$60 \mathrm{~km}$} & \multirow{2}{*}{26 日 } & \multirow{2}{*}{ 1 3 日 } & \multirow{2}{*}{$822 \mathrm{~km}$} & \multirow{2}{*}{2002 年 5 月 } \\
\hline & HRG-X(4 バンド) & $10 \mathrm{~m}$ & & & & & \\
\hline $\begin{array}{l}\text { IRS } 1 C \\
\text { インド }\end{array}$ & パンクロマティツク & $5.8 \mathrm{~m}$ & $70 \mathrm{~km}$ & 24 日 & $\begin{array}{l}5 \text { 日(26 度 } \\
\text { 以内) }\end{array}$ & $817 \mathrm{~km}$ & 1995 年 12 月 \\
\hline $\begin{array}{l}\text { ADEOS } \\
\text { 日本 }\end{array}$ & $\begin{array}{l}\text { AVNIR } \\
\text { (パンクロマティック) }\end{array}$ & $8 \mathrm{~m}$ & $80 \mathrm{~km}$ & 41 日 & 不明 & $797 \mathrm{~km}$ & 1996 年 8 月 \\
\hline $\begin{array}{l}\text { SPOT4 } \\
\text { フランス }\end{array}$ & $\begin{array}{l}\text { HRVIR-M } \\
\text { (パンクロマテイツク) }\end{array}$ & $10 \mathrm{~m}$ & $60 \mathrm{~km}$ & 26 日 & 1 3 日 & $822 \mathrm{~km}$ & 1998 年 3 月 \\
\hline
\end{tabular}

れらの検証結果をもとに，開発途上国における大規模地質災 害時に，高分解能光学衛星画像を活用して効率的に災害状況 を把握する手法を体系化すると共に，災害状況把握に必要な 4 つの衛星センサ特性の面から考察して，次世代の地質災害 監視衛星に必要な要件を考察した。

なお, 高分解能衛星画像とは分解能 $10 \mathrm{~m}$ よりも細かい解 像度の衛星画像を指す場合が多いが，本論文では空中写真と 同様の肉眼判読を対象としていることから，2.5 m よりも細 かい分解能の人工衛星画像を対象とした.

\section{地質災害の状況判読に活用できる高分解能光学衛星画像}

筆者らはこれまでに, 各種高分解能衛星画像や空中写真の 画素数を間引いて高分解能衛星画像と同程度の分解能にシ ミュレーションした画像について，大縮尺地形図作成の視点 から地物判読特性の整理を行ってきた（衛星リモートセンシ ング推進委員会空間データワーキンググループ, 2002; 小荒井 ほか, 2002, 2005, 2008a など)。また, 2005 年 10 月 8 日に 発生したパキスタン北部地震をはじめとして，非常に大規模 な災害があった際に，web 上で公開されている高分解能衛星 画像も含めて各種衛星画像を活用して, 被害状況の把握とそ の地形学的な視点からの特性把握を試みている（佐藤ほか, 2005; Sato et al., 2006, 2007; Koarai et al., 2006; 佐藤, 2007 など）※脚注 1 .

現在，日本で比較的入手が容易な光学系高分解能衛星画像 を第 1 表に示す。対象は, QuickBird（分解能 $0.6 \mathrm{~m}$ ), IKONOS (分解能 $1 \mathrm{~m}$ ), ALOS PRISM (分解能 $2.5 \mathrm{~m}$ ), SPOT5（分解能 $2.5 \mathrm{~m}$ ） などである.この表では分解能が $10 \mathrm{~m}$ よりも細かいものを取り上げた. これらの高分解能衛 星画像は，大きく 2 つのグループに分けられる.

1 つは分解能 $1 \mathrm{~m}$ クラスの商用高分解能衛星画像である.
IKONOS では $1 \mathrm{~m}$ 分解能のパンクロマティック画像と $4 \mathrm{~m}$ 分解能のマルチカラー画像の合成により $1 \mathrm{~m}$ 分解能のパン シャープン画像と呼ばれるカラー画像を作ることができる. より分解能の高い QuickBird についても同様で, $0.6 \mathrm{~m}$ 分解 能のパンクロマティック画像と $2.4 \mathrm{~m}$ 分解能のマルチカラー 画像の合成により $0.6 \mathrm{~m}$ 分解能のパンシャープン画像と呼ば れるカラー画像を作ることができる. これらの商用高分解能 衛星画像はポインティング機能（衛星の姿勢制御により軌道 直下から離れた地域を撮影する機能）によりステレオ撮影が 可能であるが，これは特別なリクエスト発注が有つた場合に 行われる. アーカイブされている画像や web 等で公開され ている画像は単画像がほとんごである。これらは観測幅が約 $11 \sim 17 \mathrm{~km}$ と広くないことと，商用であるために高価で, 広域をカバーして利用するには経費の面でも必ずしも向いて いない.

もう一つのグループは, 分解能 $2.5 \mathrm{~m}$ クラスの衛星画像で ある.こちらは観測幅が約 $60 \sim 70 \mathrm{~km}$ 程度と大きく, 少数 の衛星画像で広域を力バーすることが可能である．代表例は フランスの衛星であるSPOT5 であるが，ポインティング機 能によるステレオ撮影が可能であり, アーカイブされたデー 夕からステレオペアになる画像の組合せを選び出すことも容 易である。 また 2006 年 1 月に日本が地球観測衛星 ALOS 「だいち」を打ち上げたが, $2.5 \mathrm{~m}$ 分解能のステレオ撮影に 特化したセンサ PRISM が搭載されており, SPOT5 でのステ レオ画像よりも高い判読特性が期待されている. PRISM は 前方視, 直下視, 後方視の 3 方向に固定したセンサからな り，単一軌道上でステレオ視可能な画像のペアが得られる. しかし, ポインティング機能を有していないため, 同一箇所 は衛星の周回周期である 46 日ごとでないと撮影ができない ため，必ずしも災害状況把握に向いていない。 
なお，本研究で使用した $1 \mathrm{~m}$ クラス分解能の商用高分解能 衛星画像については, web 等で公開された単画像を中心に使 用した。一方, $2.5 \mathrm{~m}$ クラス分解能の衛星画像については, ステレオペアの画像を使用した。 そのため, 分解能の違いに よる災害状況判読特性の違いだけでなく, 単画像とステレオ 画像の災害状況判読特性の違いについても考察して整理し た.

IKONOS 画像の配信を行っているスペースイメージング社 の web サイトでは，自由にスクロールや拡大ができ，拡大 して使用している範囲では，IKONOS の画像を購入してモ二 夕上で使用した時と比べて遜色は無かった. 日立ソフトウェ アエンジニアリング社の web サイトでは自由にスクロール や拡大ができないが，QuickBird 画像を購入してモ二夕上で 使用したときと比べて遜色は無かった. したがって，web 配 信にあたつての圧縮処理で判読特性が落ちていないものと判 断した。. また衛星画像の接合処理については, 衛星画像の観 測幅が約 $11 \sim 17 \mathrm{~km}$ 程度のため, 今回公開されている画像 は 1 シーン内で収まる範囲であり，接合処理はなされていな いものと判断した.

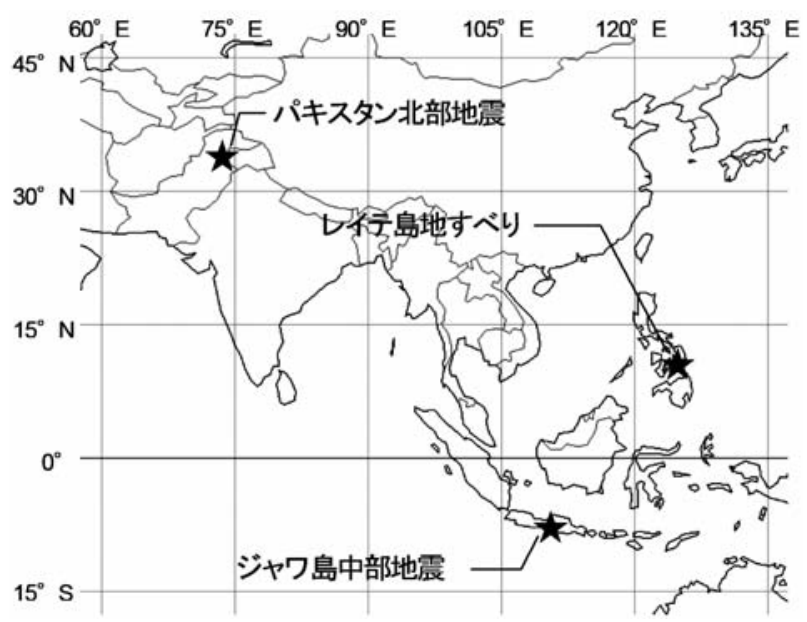

第 1 図. 対象とした地質災害の位置図

\section{対象とした地質災害の概要と判読に使用した画像}

対象とした地質災害の概要と, 各災害において災害判読特 性の比較検証に活用した画像は以下の通りである. 災害発生 箇所を第 1 図に示す。また, 各地質災害で出現した災害状況 と判読に使用した衛星画像を第 2 表に示した.

\section{1. パキスタン北部地震}

2005 年 10 月 8 日 8 時 50 分（日本時間 12 時 50 分）ご ろ，パキスタンの首都イスラマバードの北北東約 $90 \mathrm{~km}$ を 震源として，マグニチュード (Mw: 7.6: USGS)（震源の深さ 約 $10 \mathrm{~km}$ ）の地震が発生した. 震央から $100 \mathrm{~km}$ 以内の地域 は，激しい摇れに襲われ，最終的な死者は 9 万人を超えた.

パキスタン北部地震の震源地域にあたるカシミール地方 は，インドプレートとユーラシアプレートの衝突によって形 成されたヒマラヤ山脈の西端に当たる. パキスタン地質調査 所の 100 万分 1 地質図 (Geological Survey of Pakistan, 1993）によると，次のような地質構造となっている（第 2 図)。この付近の地質構造は, ほぼ東西に延びる帯状構造で 特徵付けられる. 主境界スラストが北西一南東方向に延び, スラストの北東側にカンブリア紀の堆積岩起源の変成岩, 南 西側に中新世の砂岩, シルト岩等が分布している. 今回の地 震では，バラコットーガリ断層が活動した（Kumahara and Nakata, 2006; 熊原・中田, 2007)。本断層はバラコットから ムザファラバードにかけては中新統分布域の南西縁付近を, ムザファラバードより南東では中新統の分布域内を, 北西一 南東方向に延びている. この活断層は北東傾斜の逆断層であ り，今回の地震による斜面崩壊は断層の北東側（上盤側）に 集中している (Sato et al., 2006)。この集中域は主に中新統 の堆積岩類の分布範囲に相当する．また，バラコットーガリ 断層の中央部にムザファラバード，北西端付近にバラコット があり，ここでの被災が著しかつた。

災害状況把握の判読には, $1 \mathrm{~m}$ クラス分解能の画像につい ては web で公開された IKONOS 画像とQuickBird 画像の夕 を使用した. IKONOS 画像については, スペースイメージン グ社の HP (http://www.spaceimaging.com/gallery/AsiaEQ Viewer.htm）で公開されているムザファラバード周辺の地 震前の単画像（2002 年 9 月 15 日または 22 日撮影）と地震 後の単画像（2005 年 10 月 9 日撮影）を使用した。いずれ

第 2 表. 災害ごとの被害の種類と判読に使用した衛星画像.

\begin{tabular}{|c|c|c|c|c|c|c|c|}
\hline \multirow{2}{*}{ 災害名 } & \multicolumn{3}{|c|}{ 被害の種類 } & \multicolumn{3}{|c|}{ 判読I使用した衛星画像 } \\
\cline { 2 - 7 } & 斜面崩壞 & 建物被害 & 断層変位地形 & QuickBird & IKONOS & ALOS PRISM & SPOT5 \\
\hline $\begin{array}{c}\text { パキスタン } \\
\text { 北部地震 }\end{array}$ & 0 & 0 & 0 & 0 & 0 & - & 0 \\
\hline $\begin{array}{c}\text { ジャワ島 } \\
\text { 中部地震 }\end{array}$ & - & 0 & - & - & 0 & 0 & - \\
\hline $\begin{array}{c}\text { レイテ島 } \\
\text { 地すべり }\end{array}$ & 0 & 0 & - & 0 & - & 0 & - \\
\hline
\end{tabular}



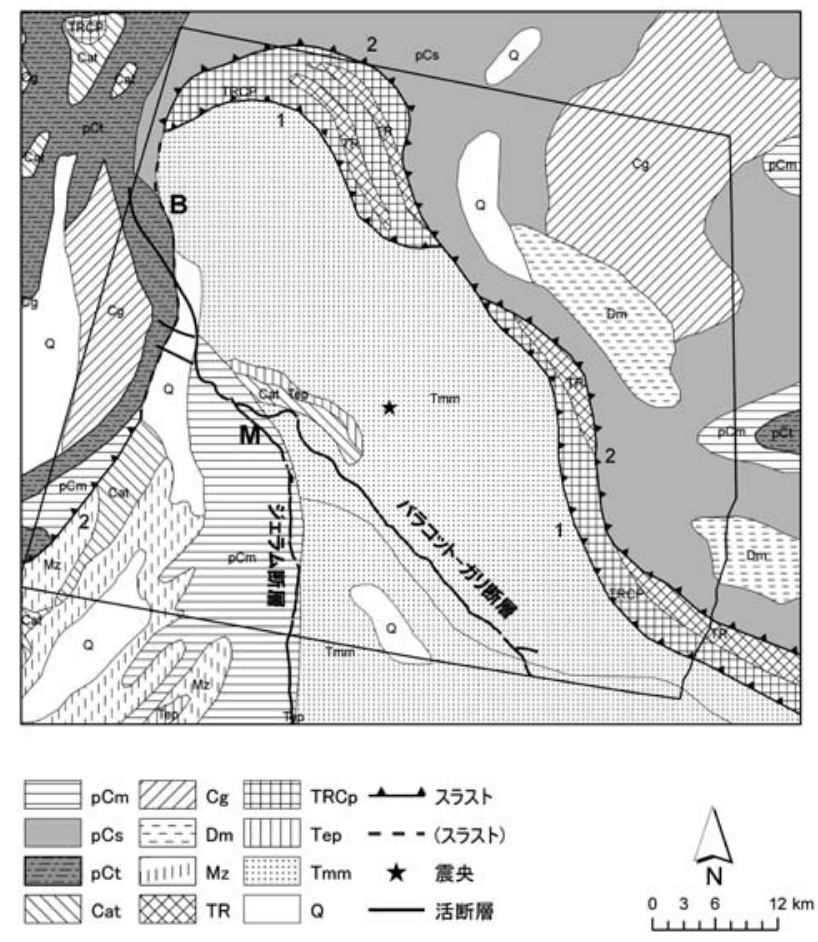

第 2 図. パキスタン北部地震震源域周辺の地質図. Geological Survey of Pakistan (1993) を修正. 活断層は, Kumahara and Nakata (2006) による. M: ムザファラバード， B: バラコット， 1: 主境界衝上断層，2: パンジャル衝上断層. 囲及線は SPOT5 のステレオ画像の範囲. pCm: 先カンブリア系の岩石, pCs: 先 カンブリア系の変成岩, pCt: 先カンブリア系の変成岩と堆積 岩, Cat: カンブリア系の堆積岩 (石灰岩, ドロマイト, シルト岩, 砂岩), Cg: カンブリア系の火成岩 (花崗岩), Dm: デボン系の 珪岩, ドロマイト, Mz: 中生界の堆積岩, TR: 三畳系の堆積岩, TRCp: 三畳系〜白亜系の岩石 (火山岩, 堆積岩), Tep: 暁新統〜 始新統の堆積岩 (石灰岩, 頁岩), Tmm: 中新統の堆積岩 (砂岩, シルト岩), Q: 完新統.

も, 分解能 $1 \mathrm{~m}$ のパンシャープン画像である. QuickBird 画像については, 日立ソフトの HP (http://hitachisoft.jp/ News/News350.html） で公開されているバラコット周辺の 地震前の単画像（2005 年 8 月 11 日撮影）と地震後の単画 像（2005 年 10 月 19 日撮影）を使用した. いずれも, 分解 能 $0.6 \mathrm{~m}$ のパンシャープン画像である. また, Google Earth でも被災地域の画像を広域にわたつて公開しており，使用し ている画像は QuickBird 画像である. 広域的な災害状況を 把握するため, 被災地全域について地震後の SPOT5 ステレ オペア画像（2005 年 10 月 20 日, 10 月 27 日撮影）と地震 前の SPOT5 単画像（2004 年 3 月 2 日撮影）を入手し判読 を行つた.

\section{2. ジャワ島中部地震}

2006 年 5 月 27 日 5 時 54 分頃 (日本時間 7 時 54 分頃), インドネシアのジャワ島中部のジョグジャカル夕近傍でマグ ニチュード (Mw: 6.3: USGS) の地震が発生し, 死者約 5000 人の大災害となった. 震源はジョグジャカル夕市から南南西 へ約 $30 \mathrm{~km}$, 深さ約 $12 \mathrm{~km}$ と推定されている.

UNOSAT（国連衛星プロジェクト）が衛星画像から推定さ

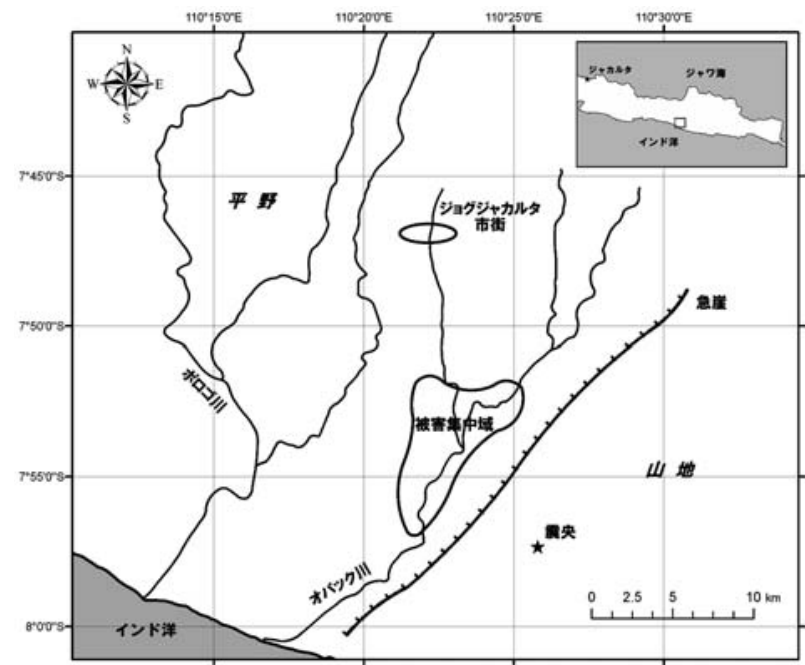

第 3 図. ジャワ島中部地震の被害域とその周辺の地形. UNOSAT（国連衛星プロジェクト, http://unosat.web.cern.ch/ unosat/freeproducts/indonesia/UNOSAT_Java_EQ_damage30may0 6_highres.jpeg）の資料を元に編集.

れた被害分布と震央位置との比較を示したものを第 3 図に示 した．被害集中域は，ジョグジャカル夕市街から南に $10 \mathrm{~km}$ ほど離れたオパック川流域に存在する.この地震を発生させ たのは，ジャワ島中部を南北に走る活断層（オパック断層） の活動と考えられている (Irwan ほか, 2006). ジョグジャカ ル夕市街地の南東側には山地が広がっており, 平野部との境 界には急崖が形成されている. この急崖に沿う形で北東一南 西方向数 $10 \mathrm{~km}$ にわたつて活断層が連続している. 震央に 近い活断層に沿つた平野部で，大きな被害が集中しているこ とがわかる。

災害状況把握に使用した衛星画像は, IKONOS 画像につい ては, シンガポール大学の HP (http://www.crisp.nus. edu.sg/earthquake20060527/index.html）で公開されている ジョグジャカルタ周辺の分解能 $1 \mathrm{~m}$ のパンシャープン画像 (地震前 2006 年 5 月 9 日撮影の単画像, 地震後 2006 年 5 月 28 日撮影の単画像) を使用した. ALOS PRISM 画像につい ては, 国土地理院と宇宙航空研究開発機構 (JAXA) との共 同研究協定により, 地震後 2006 年 6 月 12 日撮影の $2.5 \mathrm{~m}$ 分解能パンクロマティックのステレオ画像の提供を受けた.

\section{3. レイテ島地すべり}

2006 年 2 月 17 日 10 時 36 分頃（日本時間 11 時 36 分 頃), 南レイテ島サンベルナルド町ギンサウゴンで, 集落の 西側にある比高 $800 \mathrm{~m}$ に近い急崖が崩壊し, 大規模な土砂 災害が発生した.この土砂災害により集落は完全に埋没し, 死者 154 人，行方不明 990 人という大惨事になった.

災害発生原因は，災害前に降つた大量の降雨が誘因と考え られている. レイテ島では 2006 年 2 月 1 日より断続的な降 雨が観測され, 災害が発生した 2 月 17 日までの被災地の南 西約 $40 \mathrm{~km}$ に位置するマーシン（被災地に最も近い気象観 測地点）における累積雨量は $627 \mathrm{~mm}$ に達している. なお, 災害発生の前後に地震が観測されているが, 災害との関連性 

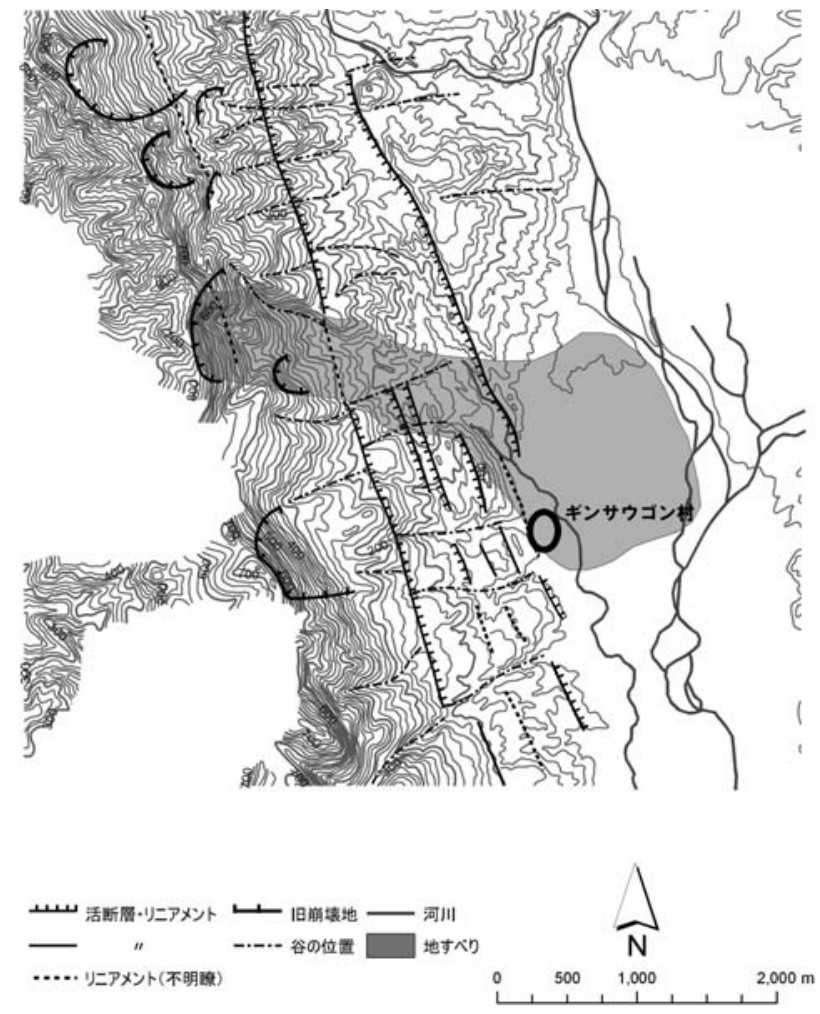

第 4 図.レイテ島地すべり周辺の地形。等高線は NAMRIA 作成 5 万分 1 地形図から作成. 活断層・リニアメント, 旧崩壊地, 谷の位置等は 1952 年撮影の米軍空中写真の判読による（縮尺 約 1/35,000: コース $344-11 \sim 13,345-23 \sim 25$ ).

\section{については現時点では不明である。}

調査地域の山地は全体として西に傾動する地塊を形成して おり, 分水嶺が東側に局在し東斜面は急崖を形成している. 今回の大規模山体崩壊はその急崖で発生した (第 4 図)。崩 壊土量は約 $2.9 \times 10^{7} \mathrm{~m}^{3}$ である（消防研究センターほか, 2007). その急崖の基部に南北に延びる断層地形が明瞭に判 読できるが，これはフィリピン中央断層の延長部にあたる (諏訪, 2006).1952 年撮影の米軍空中写真（縮尺約 1/35,000: コース $344-11 \sim 13,345-23 \sim 25)$ により判 読すると, 急崖に平行して南北方向の高度不連続や鞍部の直 線的配列が認められ, 数本のリニアメントが存在する. 高度 不連続の大きい一番西の東側低下のリニアメントと一番東の 西側低下のリニアメントは, 谷線の不連続（左横ズレ）や三 角末端面が認められることから, 活断層の可能性が高いもの と判断される. また, 急崖の頂部に沿つて崩壊地形がいくつ か確認でき, この急崖がさまざまな箇所で崩壊を何度も起こ していたことがわかる.

レイテ島の地質は，フィリピン地質図（http://tvipacific. com/main/) によると第三系から第四系の堆積岩類とされて おり，被災斜面の地質については，上野・地下（2006）によ ると, 崩壊源頭部は火山角碩岩，デイサイト質凝灭岩，角閃 石デイサイトなどの火山岩及び火山砕屑岩類から構成されて いる.

雨天のため被災直後の高分解能光学画像は撮影できなかつ
たが, 2006 年 4 月 16 日と 18 日撮影の QuickBird パンシャ ープン単画像を入手した。 また ALOS PRISM 画像について は, 国土地理院と JAXA との共同研究協定により, 2006 年 10 月 10 日撮影の前方視・直下視・後方視 3 つのステレオ画 像の提供を受けた.

\section{衛星画像の災害判読特性の比較検証方法}

各種光学高分解能衛星画像の災害状況判読特性の整理にあ たつては, 同一の災害状況について異なる分解能の画像で判 読したものを, 1 枚の判読事例カードとして整理し, それを 基に考察を行った. 実際の衛星画像判読にあたつては, 様々 な条件下での判読が想定される. 例えば, コンピューターの ディスプレイ上で判読する場合もあれば, 出力紙に打ち出し て印刷した画像を判読する場合もある. また，実体鏡を使用 して立体視を行って判読する場合もあれば, 肉眼立体視で判 読を行う場合もある. したがって, 今回の判読事例カードの 作成にあたつては, 判読方法は限定せず, 判読条件のみ明記 してその条件下での判読結果を記載した.

その結果, 入手した衛星画像に関しては漏れなく判読を行 ったパキスタン北部地震を中心に, 50 枚以上の判読カード を作成した. その代表例として, パキスタン北部地震におけ るムザファラバード近郊の橋梁被害の事例を第 5 図に示す. 判読力ードの設計の基本的な考え方は, 筆者がこれまで大縮 尺地形図作成に必要な地物の判読特性を整理したときの基準 (衛星リモートセンシング推進委員会空間データワーキング グループ, 2002）を踏襲した.

上段には $1 \mathrm{~m}$ クラス分解能の衛星画像を貼り, 単画像であ るため災害前の画像と災害後の画像をそれぞれ比較できるよ うに並べた。 中段には $2.5 \mathrm{~m}$ クラス分解能の衛星画像を貼 り, 災害前の画像 1 枚と災害後のステレオペア画像を, ステ レオ画像については実体視出来るように並べた。 下段は，判 読条件及び判読可能性について記述した. 判読条件及び判読 可能性は, 分解能の違う衛星画像毎に以下のような記号で記 載した。

判読条件は以下のとおりである.「判読したもの」につい ては, ディスプレイ上で判読した場合には「D」, 出力紙で判 読した場合は「P」と表示した。「判読したものの縮尺（倍 率)」については, 衛星画像を縮尺 $1 / 25,000$ 相当で表示・出 力して判読した場合は「 $25 \mathrm{k} 」$, 縮尺 $1 / 2,500$ 相当で表示・出 力して判読した場合は「2.5k」と表示した.「判読方法」に ついては，実体鏡を使用した立体視の場合は「Ss」，実体鏡 を使用しない肉眼立体視の場合は「Sb」, 単眼視の場合は 「M」と表示した。「判読した画像」については, 判読事例力 ードで出力した固定倍率で判読した場合には「F」, 画像の倍 率を変え画像を広域に見て判読した場合を「V」と表示した。 「判読可能性の記号」については, 容易に判読可能な場合を 「○」, 判読可能な場合を「○」, 判読にやや困難がある場合 を「 $\triangle 」$, 判読が不可能な場合を「メ」と，4段階に分けて 表示した.「判読上の特徵」については, 地上分解能の違い や単画像とステレオ画像の違いおよび判読条件による違い等 を記載した。 また，災害状況を推測する観点から所見を記載 




第 5 図. 高分解能衛星画像の災害判読特性カードの例. D: ディスプレイ上で判読 P: 出力紙上で判読 $25 \mathrm{k}: 1 / 25,000$ 相当で判読 $2.5 \mathrm{k}: 1 / 2,500$ 相当で判読 Ss: 実体鏡による立体視 Sb: 肉眼立体視 M: 単眼視 F: 固定倍率による判読 V: 画像の倍率を変えて判読 ○: 容易に判読可能 $\bigcirc$ : 判読可能 $\triangle$ : やや困難 $\times$ : 判読不可能. 
した.

なお，ディスプレイ上で判読するときに， CRT や液晶モ 二夕の性能によって結果が異なる可能性はあり得るが，今回 の画像判読では同一のモニ夕を使い, 全てカードに打ち出し て判読しているので，条件の差はないと考えられる．使用し たディスプレイは SONY カラー液晶ディスプレイ「SDMM81」で，画面サイズ 18.1 型（CRT20 型相当）, 最大解像 度 $1280 \times 1024$ ドット，表示色数 1677 万色相当である.

\section{光学系高分解能衛星画像による地質災害状況の判読結果}

\section{1. 斜面崩壊の判読}

ジャワ島中部地震では, 被害の多くが平野部での建物被害 であったため, 斜面崩壊の判読はパキスタン北部地震とレイ テ島地すべりを対象に行った.

1）パキスタン北部地震による斜面崩壊の判読 パキスタン 北部地震に関しては，SPOT5 のステレオ画像を実体視判読 し, 地震前の単画像と比較することにより, 地震により発生 した斜面崩壊の分布を全体的に把握した（第 6 図）。SPOT5 は観測幅が広いため, 斜面崩壊域をほぼカバーして判読が可 能であった． 全体で 2424 の斜面崩壊が判読されている. 斜 面崩壊は既存の活断層（バラコットーガリ断層; Kumahara and Nakata, 2006）に沿つて断層の北東側（逆断層の上盤 側）に集中して発生しており, 衛星 SAR で把握した地震に よる地殼変動の大きな領域（Fujiwara et al., 2006）と一致 している，特に，断層が屈曲する位置にあたるムザファラバ 一ド北部に大規模な斜面崩壊が集中している．また，断層の 南西側には大規模な崩壊はわずかしか確認できなかった。な お，一部断層線から離れた領域にも斜面崩壊が集中するのが 確認出来るが，その原因については特定できない.

一方 IKONOS 単画像の判読では, 画像の範囲内で約 100 ヶ所の斜面崩壊が確認できた。同じ範囲を SPOT5 画像のス テレオ画像で判読すると, 初期判読段階で約 50 個の崩壊が 抽出できる. IKONOS 画像は分解能が良いため, IKONOS 画像での夕判読可能な斜面崩壊としては, 浅い表層崩壊, 切 土部での小規模な崩壊，地すべりの滑落崖，亀裂（第 7 図: 左が地震前, 右が地震後の画像) などがある. 斜面崩壊等の 地表変動は，小規模なものや浅い表層崩壊でない限りは 2.5 $\mathrm{m}$ 分解能でも判読可能であり, 土砂崩壊により寸断された道 路（第 8 図）なども判読できる。

2）レイテ島地すべりの判読 レイテ島地すべりについては, QuickBird 画像はオフナディア角（衛星のセンサがポインテ イング機能を使って撮る角度）が $40^{\circ}$ 以上と大きく，実質的 な地上分解能は $1.5 \sim 2 \mathrm{~m}$ 程度であるが，カラー画像である ため堆積域の色調の違いが明確で，堆積域の細かな地形の違 いが容易に判読できる．今回の土砂災害地域は大きく崩壊 域・流送域・堆積域に 3 区分でき，単画像のため高低感がつ かみにくいが，流れ山の存在も確認できる，また，崩壊域や 流送域に巨碟が残っている様子も確認できる. 第 9 図に堆積 域の QuickBird 画像を示すが，流れ山地形は概ね下流に行 くほど長径・短径・比高が小さくなる，流れ山堆積域の上流 側では大型の流れ山が集中しているのに対し，下流側では小
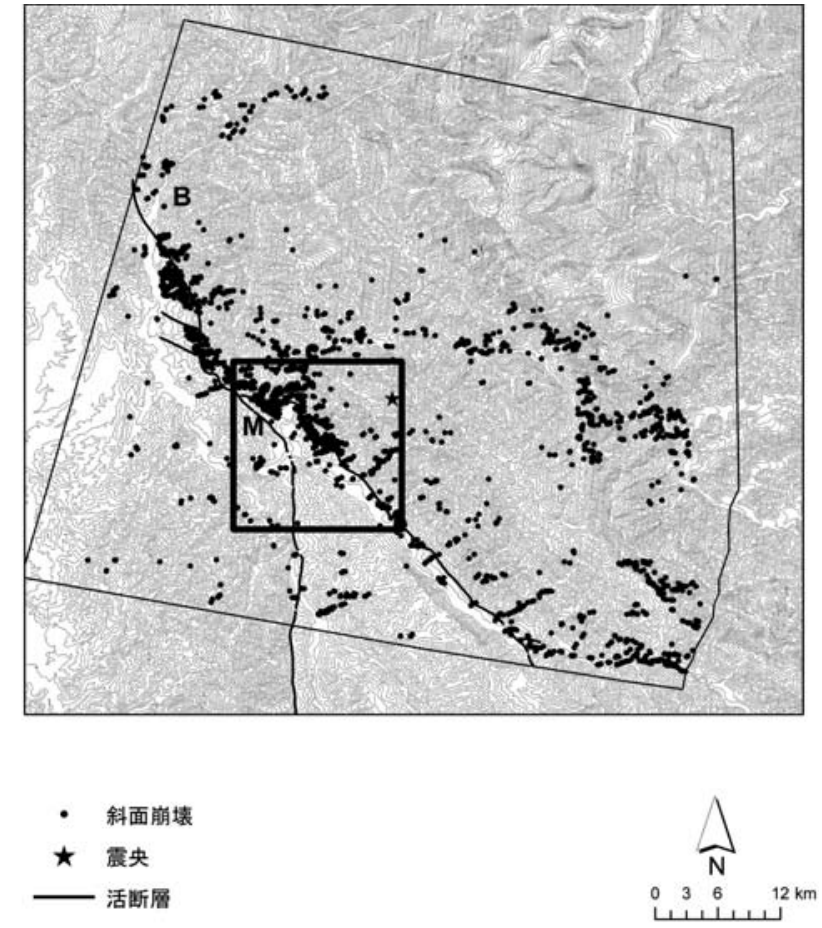

第 6 図. パキスタン北部地震による斜面崩壊の分布. 斜面崩壊 の分布は, Sato et.al. (2006) による. 等高線は SRTM のシャト ル SAR のデータから作成. 活断層は, Kumahara and Nakata （2006）による. 細線囲みは, SPOT5 ステレオ画像の範囲. 太 線囲みは IKONOS 単画像の範囲. M: ムザファラバード, B: バ ラコット。

型の流れ山が集中している．長径の配列は，画像を判読する 限り，上流域では長径が流下方向に対して直交しているもの が多く，下流部では逆に平行方向であるものが多い。また， 土砂堆積物の末端では㱀状の地形が判読できるが，これは流 れ山がまとまって帯状に配列し, 凹部に帯水したものであ る.

一方, ALOS PRISM 画像は，崩壊部が雲に覆われており, 流送域の一部と堆積域のみ判読が可能である. 分解能が 2.5 $\mathrm{m}$ とやや粗く細かい地形の判読は困難であるが, 実体視が可 能であるため, 流れ山等の高低感が決め手になる地形の判読 は容易である，現地調査では，災害現場周辺の道路交差点・ 橋梁等の GCP (Ground Control Point: 画像に位置座標を与 える基準となる点）でGPS 測量を行い，この結果を基に幾 何補正した PRISM 画像から流れ山地形を図化して, 流れ山 地形の形状や物理量 (長径, 短径, 長径の卓越方向, 面積, 周 長, 流送距離など) について定量的に計測することができた (消防研究センターほか, 2007)。 その結果からも, Quick Bird 単画像の判読から把握された流れ山地形の長径の配列 の特徵についても, 定量的に明らかにされた（小荒井ほか, 2007, 2008b).

\section{2. 建物被害及びその他の施設被害の判読}

建物被害の判読については, パキスタン北部地震, ジャワ 島中部地震, レイテ島地すべりの 3 つの災害について被災状 況の判読を行った. 被害の判読にあたっては, 判読の容易さ 

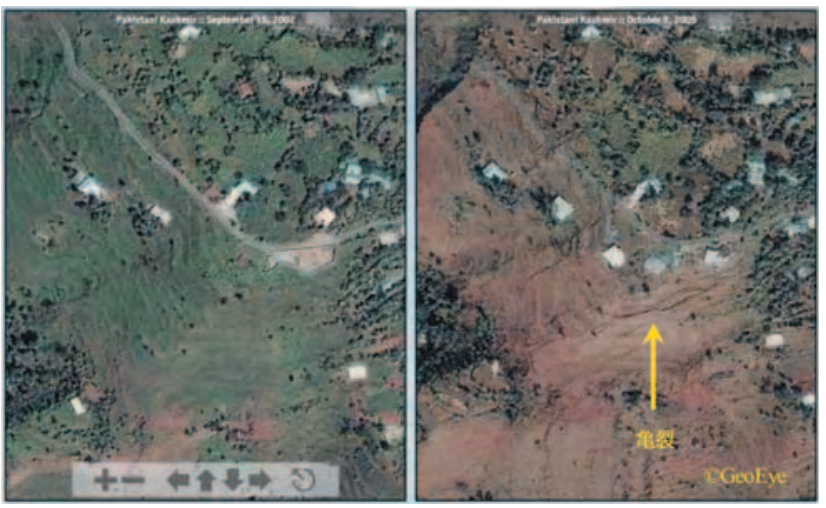

第 7 図. 地震による亀裂の IKONOS 画像. 左: 地震前（2002 年 9 月 15 日撮影), 右: 地震後 (2005 年 10 月 9 日撮影).
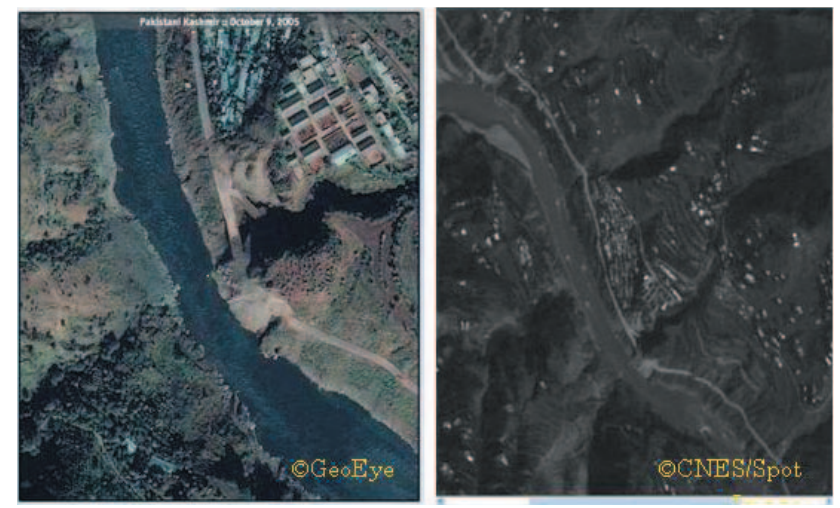

第 8 図. 崩壊による道路の不通. 左: IKONOS 画像 (2005 年 10 月 9 日撮影), 右: SPOT5 画像 (2005 年 10 月 20 日撮影).

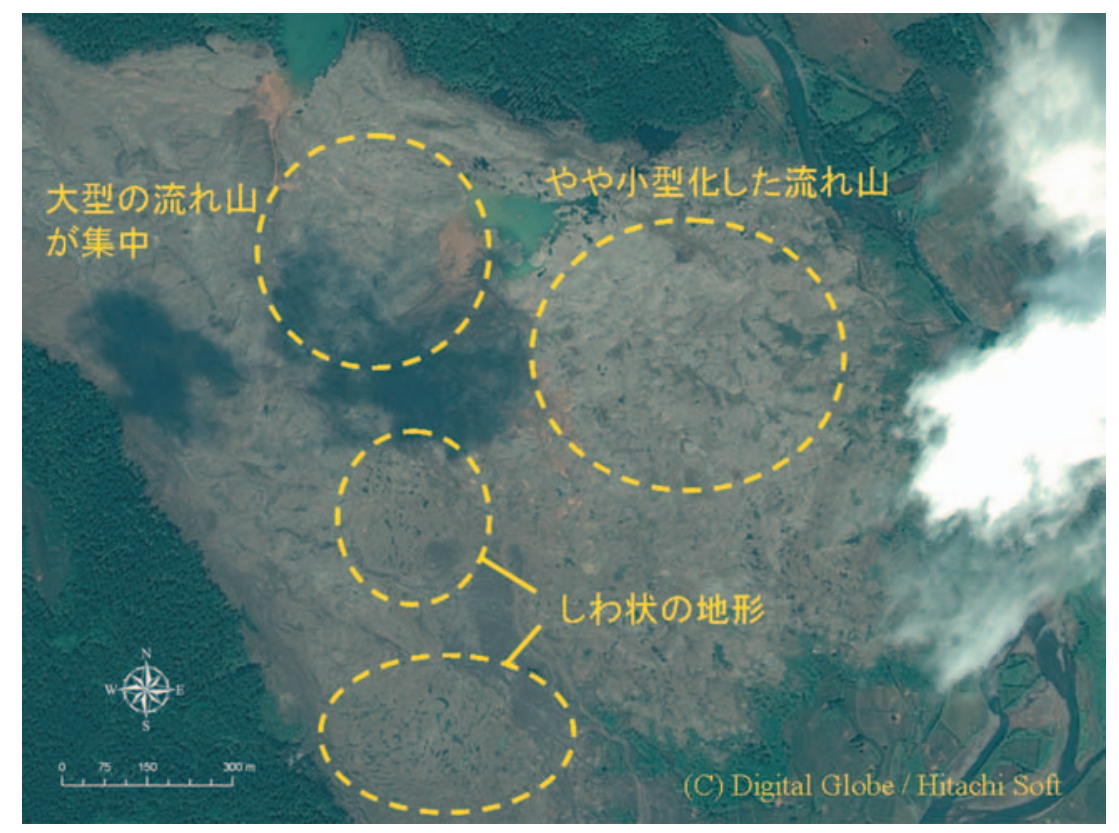

第 9 図. レイテ島地すべり堆積域の QuickBird 画像（2006 年 4 月 16 日撮影）。
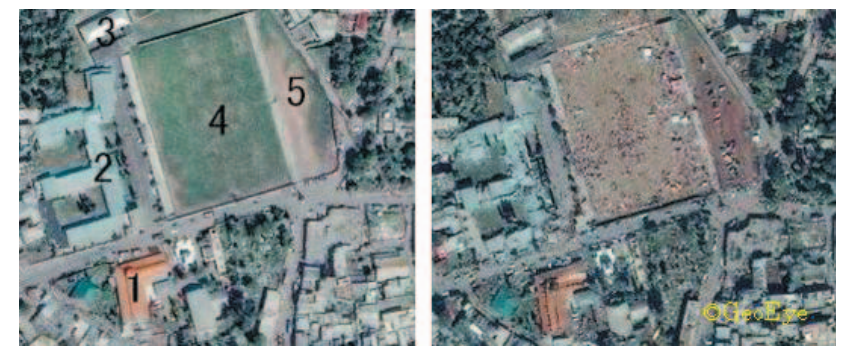

第 10 図. ムザファラバード市街の IKONOS 画像（佐藤ほか, 2005 より). 左: 地震前 (2000 年 9 月 22 日撮影), 右: 地震後 (2005 年 10 月 9 日撮影)。画像中の数字は本文中で説明用に使 用.

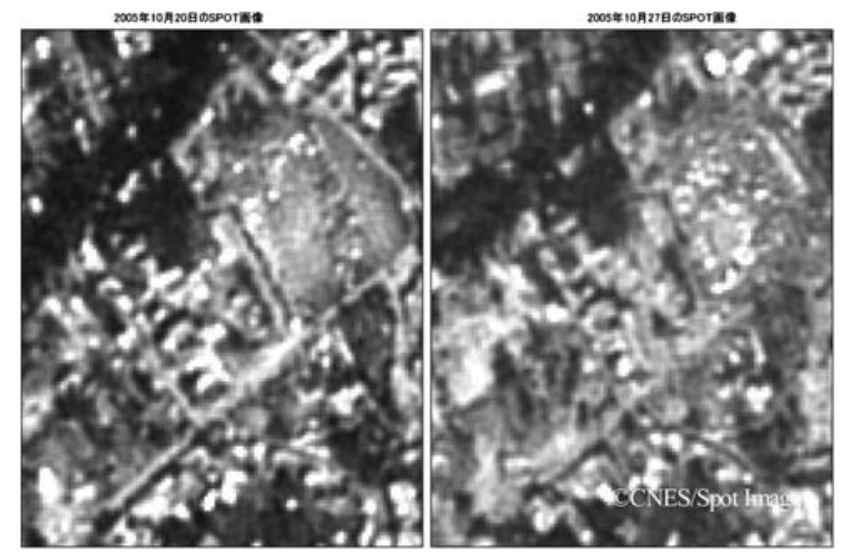

第 11 図. ムザファラバード市街の地震後の SPOT5 ステレオ画像 (第 10 図と同じ箇所). 
を次の指標に着目して整理した. (1)被害建物が大きな建物で あるか否か. (2)市街地のように建物が密集している地域であ るか，郊外のように建物が散在している地域であるか。（3壊 滅的な建物被害が集中している地域であるか，建物被害が散 在している地域であるか. 以上の 3 点である.

1）パキスタン北部地震での建物被害の判読 パキスタン北 部地震については, IKONOS 画像を用いたムザファラバード 市街中心部の建物被害の状況が報告されている（佐藤ほか, 2005). この場合, 建物そのものの 1 軒ごとの判読は可能で あるが, 単画像ということもあり, 個別の建物被害までは, 大きな建物を除いては判読困難であった. 第 10 図はムザフ アラバード市街中心部の IKONOS 画像である.「1」の茶色 の建物が，地震後には屋根の骨組みのような構造が見え損壊 している.「2」については，上から見ると片仮名の「ヨ」状 の構造は維持しているものの，「ヨ」の縦棒の相当箇所が全 壊している.「3」の建物は, 左半分はかろうじて屋根の形状 を維持しているものの, 右半分の外縁は歪んでおり, 半壊し ている.「4」のグラウンドには，テントらしきものが見え， 人々が避難しているように見える.「5」は地震前と比較して 地面が茶色く，土壌が水分を含んでいるようである．この画 像に見られる他の一般建物については, どの程度の被害が出 ているのかについては判読できない.ムザファラバードにつ いては，被害が出ている建物と出ていない建物が混在してお り，このような被害集中状況だと，大きな建物の被害状況な ぞは単画像でも判読可能であるが，小さな建物まで含めた建 物被害の網羅的マッピングは困難である.

他の画像の例を見る.ムザファラバード市街中心部におけ る第 10 図の IKONOS 画像と同じ箇所の SPOT5 画像を第 11 図に示す。建物等が集中している都市部が存在すること は判読できるが，画像を拡大した場合でも建物 1 軒ごとの判 読は困難であり，建物被害の判読も不可能である. 第 12 図 はバラコット市街中心部の地震後の QuickBird 画像である. 単画像ではあるが建物一軒一軒の被害の判読も可能である.

その他の施設被害状況の判読としては, IKONOS 単画像で 橋梁の破壊, 道路の不通・損壊（土砂崩落による）, 河川の 濁りなどが判読された. 特に郊外部では小規模な崩壊によつ て道路が不通であっても, 道路が何かで覆われていれば判読 が可能であった. SPOT5 ステレオ画像については，郊外部 においては道路の存在については判読可能であるが, 道路の 不通・損壊状況は, 大規模な斜面崩壊等によるものの夕判読 が可能であった.

2）ジャワ島中部地震，レイテ島地すべりでの建物被害の判 読 ジャワ島中部地震の建物被害状況については, 分解能 1 m の IKONOS 画像では，建物散在域では建物 1 軒ごとの災 害状況の判読は可能である (第 13 図左). 色調が変化してい る液状化の可能性がある耕作地も判読できた。一方，建物密 集域では 1 軒ごとの被害を網羅的に把握することは困難で, 建物被害集中域の判読のみが可能であった（第 13 図右）。分 解能 $2.5 \mathrm{~m}$ の ALOS PRISM 画像では, 分解能の関係で IKONOS 画像ほどの判読特性はないが, 実体視することによ り大きな建物であれば建物散在域での 1 軒ごとの被害も判読
可能であった（第 14 図）。ただし，建物散在域であっても， 大きな建物でなければ 1 軒ごとの被害の判読は不可能であ る.

レイテ島の地すべりに関しては，現地調査で土砂に埋もれ て倒壊した建物や山体崩壊の際の疾風で倒壊したと推測され る建物が確認できたが，QuickBird 画像でもその存在は確認 できた (第 15 図). ただ単画像のために倒壊状況については 画像だけでは判断困難である。一方 ALOS PRISM 画像は, 何らかの構造物が存在することは判読できるが, それが倒壊 した建物であることは判読不可能である.

\section{3. 断層変位地形の判読}

地表地震断層等の断層変位地形の判読特性については, そ れが出現したパキスタン北部地震についてのみ述べる. 災害 直後に公開された IKONOS 単画像では, 地震断層の存在や 河岸段丘の変位については, はっきりしたものは確認できな かつた䀧 1). しかしながら, この地震によつて地表地震断層 が出現したかどうかは日本地理学会災害対応委員会のメーリ ングリストで, Google Earth で公開されている QuickBird の画像に関して議論があった.この経緯は宇根・熊木 (2007) に詳しく紹介されている.

1）ムザファラバード北部の断層変位地形 ムザファラバー ド北部に，河川に斜行する崖に沿つて建物被害が集中してい る地域があり, 土木学会の予備調査団速報に現地写真が示さ れている䀧 2). この場所は地形的には細長い豆状の高まりと それがなす崖に位置しており，土木学会の予備調査団速報は 地形効果により摇れが集中したために建物被害が集中したも のと解釈した. しかし, 筆者らはその写真に示されている崖 地形が河川と斜行する方向に延びていることや周辺の樹木が 広範囲にわたつて系統的に傾いているなどの特徴から, それ らが地表地震断層の可能性が高いと考え, その背後の斜面崩 壊の状況や周辺の建物や樹木の状況等からその位置を IKONOS 画像上で特定した (第 16 図)。ここでは建物の壊 滅的な被害が発生している地域が崖に沿つて線上に分布し て，そこから数 $\mathrm{m}$ 程度離れた建物にはほとんど被害が無い ことが確認できた。この場所はSPOT5 画像では第 17 図の ＃５にあたる場所であり，実体視判読したところ，かつての 河道に沿つた段丘崖で, その右岸側は河成段丘によって一段 高くなっており, 既存の河成段丘崖と同じ場所に現れた地表 地震断層の可能性がある. この可能性については, 佐藤ほか (2005), 宇根・熊木 (2007) でも報告している. その崖地 形の延長部にあたるジャラム川には斜面崩壊により河道閉塞 を起こした跡が判読されたが，その下流部で浅瀬のようにな っておりその部分で河床が隆起した可能性が指摘され, 崖地 形が断層変位地形である可能性を示唆している. その後, 産 業技術総合研究所活断層研究センターは, 現地調査の結果,

\footnotetext{
略这 2) Konagai,K., Akbar,A., Oguni,K., Kodama,H. and Ikeda,T., 2005, Provisional report of the damage caused by Muzaffarabad Earthquake of October 8, 2005, Pakistan. http://www.jsce.or.jp/report/36/index.html を参照のこと.

畔注 3) 粟田泰夫 · 金田平太郎 - 堤 浩之 - 中田 高, 2006, 現地調査による 2005 年パキスタン地震の地震断層, http://unit.aist.go.jp/actfault/katsudo/ jishin/pakistan/report01.html を参照のこと.
} 
この崖地形の基部に撓曲地形が存在し, 河谷の系統的な左屈 曲が見られることを報告している畔注3.

2）バラコット市街地の断層変位地形 バラコットの市街地 の判読は, QuickBird 画像による. バラコットにおいても丘 の西向き斜面に形成されていた旧市街地が壊滅的被害を受け ていたのに対して, その周辺の建物にはほとんど被害がなく, その対照がはっきりしており (第 12 図)，この丘の成因とし て断層変位地形が予想された（宇根・熊木，2007）。また, QuickBird 画像においてこの丘の南延長部にあたるクンハー ル川において浅瀬が見られるため, その部分が地震後に隆起 した可能性が高いと判断でき (宇根・熊木, 2007), 一連の地 形が断層変位地形である可能性が指摘できる.この地形につ いても, 産業技術総合研究所活断層研究センターは現地調查 の結果, この西向きの斜面が断層変位による撓曲崖であるこ とを確認した瞇 3).

\section{各種衛星画像の災害判読特性についての考察}

\section{1. 斜面崩壊の判読特性についての考察}

$1 \mathrm{~m}$ 分解能の IKONOS 単画像と $2.5 \mathrm{~m}$ 分解能の SPOT5 ステレオ画像と比べた場合, 浅い表層崩壊, 切土部での小規 模な崩壊，地すべりの滑落崖，亀裂など変化の小さな細かい 地形は，より高分解能のIKONOS 画像でないと判読できな いものが多かった。 しかし, 斜面崩壊は地表の土地被覆状況 が急激に変化している場合が多く, 植生のある斜面の崩壊で あれば小さな斜面崩壊であっても $2.5 \mathrm{~m}$ 分解能の衛星画像で 十分その存在は判読可能である. SPOT5 はステレオ画像な ので, 実体視した結果をオルソ化した SPOT5 画像に移写す ることにより，正確な崩壊地形のポリゴン情報を取得するこ とができた. SPOT5 画像は観測幅が大きいため, 1 つのス テレオペアでパキスタン北部地震の斜面崩壊の集中域をカバ 一できた. IKONOS 画像で斜面崩壊の範囲を全域力バーする とかなりの枚数の衛星画像が必要となることを考えると, 経 費の面から見ても全域の被害状況を明らかにする上では SPOT5 は有効であった. Sato et al.（2006）のように，全 域の斜面崩壊を一定条件で抽出し，DEM と重ね合わせて斜 面崩壊発生の地形条件を検討するような研究では, SPOT5 ステレオ画像で十分その役目を果たしていると言えよう.

今回の研究では IKONOS 画像は web で公開されている単 画像 1 枚の夕を使用したが, 同じ範囲内の SPOT5 画像と比 較した. ムザファラバード市街地を中心に $11 \mathrm{~km}$ 四方の範 囲で比較した場合, IKONOS 単画像では災害直後の初期の段 階で約 100 箇所の斜面崩壊が判読されたのに対し, SPOT5 画像によると, 初期判読段階で約 50 個の崩壊を抽出してい た. 具体的に崩壊地の中のどの様なものが判読できるのかを 比較してみる. SPOT5 画像では, 全体的な白黒のコントラ ストが悪く, 斜面崩壊の箇所が過剩に白く輝いており, 崩壊 地内の詳細な地形までの判読は困難であった. 崩壊地形が判 読できても, その崩壊が今回の地震で発生したものであるか どうかの判断は困難で, 地震発生前の SPOT5 画像と比較対 照することで判断した。一方 IKONOS 画像では, カラー画 像で分解能が高い分, 崩壊地内の土砂の堆積状況や堆積物の
新鮮さなども定性的に判断が可能であり, 災害前の衛星画像 が無くてもある程度は新鮮な崩壊であるかどうかの判断は可 能である. ただし, ステレオ画像でないために, 崩壊地の地 形について立体感をつかみにくい. 今後の 2 次災害の危険性 などを判断する上では, ステレオ画像であることが望ましい． ステレオ画像の場合, 図化する事により土砂崩壊量などを定 量的に計算することが可能となる．今回のレイテ島地すべり 災害では, ALOS PRISM ステレオ画像を使うことで，流れ 山地形の形状について定量的に評価することが可能であつ た.

\section{2. 建物被害の判読特性についての考察}

はじめに, $1 \mathrm{~m}$ クラス分解能の単画像について考察する. 小荒井ほか $(2005,2008 \mathrm{a})$ による地物の判読特性の検証て は, IKONOS 画像では堅牢建物については描画・判読ともに 可能であった. しかし，一般建物については判読可能である が描画困難であった。今回の建物被害の判読結果では, IKONOS 画像については, 建物そのものが 1 棟ごとに存在 することの判読は可能であるが, 単画像ということもあり, 個別の建物被害の状況の判読は困難であった.

ムザファラバードにおける建物被害の場合（第 10 図）の ように, 市街地内で被害を受けた建物と受けていない建物が 混在しているような被害集中状況の場合, 大きな建物の被害 状況などは単画像でも判読可能であるが，建物被害の網羅的 マッピングは困難である。 小荒井ほか $(2005,2008 a)$ による 之, 実体視判読が可能であれば, 一般建物の判読特性は高低 感が建物の判読の鍵になるので, 判読特性が向上する事が知 られており，IKONOS がステレオ画像であれば，より建物被 害の判読が向上するものと考えられる。しかし, 建物の被害 状況が半壞程度であった場合には, 分解能がより高い空中写 真による実体視が可能だったとしても，建物が被災している か否かの判読は困難である. したがって, 空中写真より分解 能の低い高分解能衛星ステレオ画像では, 半壊程度の建物被 害の判読は航空写真と同様に困難である. ジャワ島中部地震 の事例でも, 建物散在域では建物 1 軒ごとの災害状況の判読 は可能であるが (第 13 図左), 建物密集域では 1 軒ごとの 被害を網羅的に把握することは困難で, 建物被害集中域の判 読のタが可能であった (第 13 図右).ムザファラバード北部 の断層変位地形沿いでも, 同様に建物被害の集中域の判読が 可能であった. 建物 1 軒ごとの被害状況の判読は不可能だと しても, 深刻なダメージを受けた地域をいち早く知り, 災害 救助を迅速に行う上で, 重要な情報を提供できると考えられ る.

QuickBird 画像は分解能が IKONOS 画像より高いため, 判読特性が少し向上している. 小荒井ほか (2005, 2008a) は, IKONOS 画像では一般建物の判読は可能であるが, 描画 は困難と評価し, QuickBird 画像では判読・描画ともに可能 と評価した. IKONOS 画像では判読が困難な歩道・道路分離 帯・並木等の道路付帯構造物の判読も, QuickBird では可能 である (小荒井ほか, 2005, 2008a)。つまり，QuickBird 画 像は IKONOS 画像と比べて建物被害の判読が容易であった. 第 12 図のバラコットの地震後の画像では，単画像ではある 


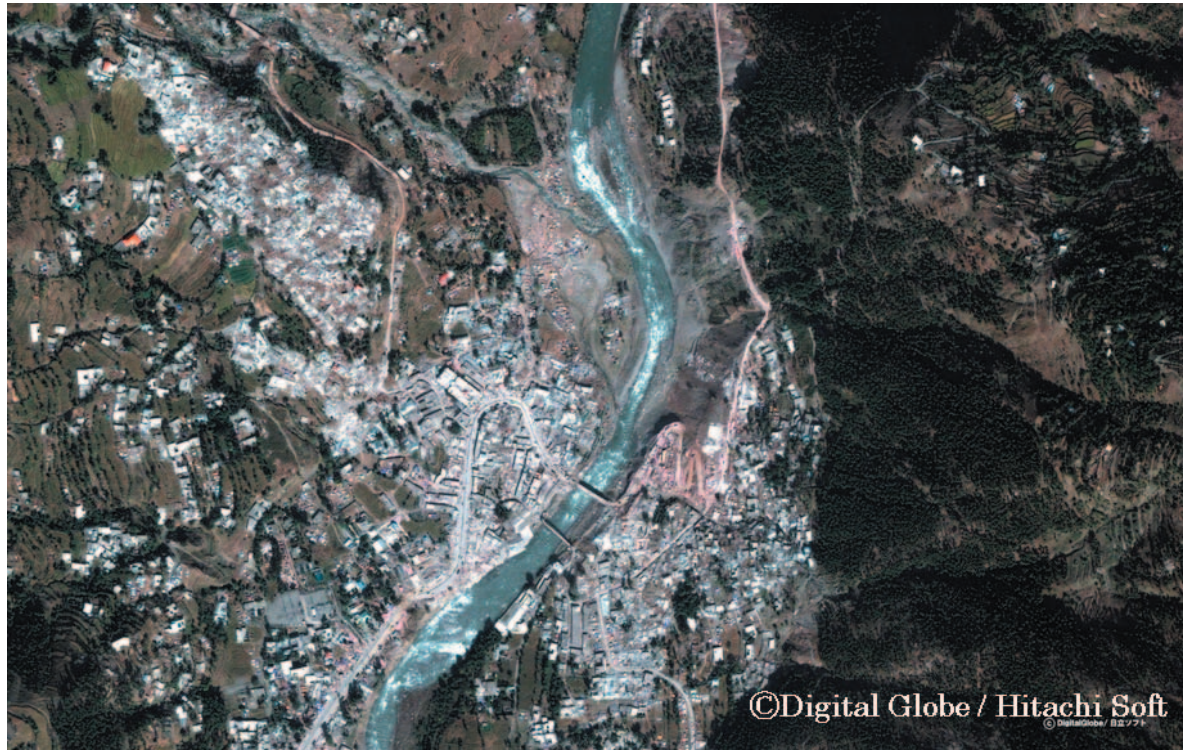

第 12 図. バラコットの地震後の QuickBird 画像（2005 年 10 月 19 日 撮影).
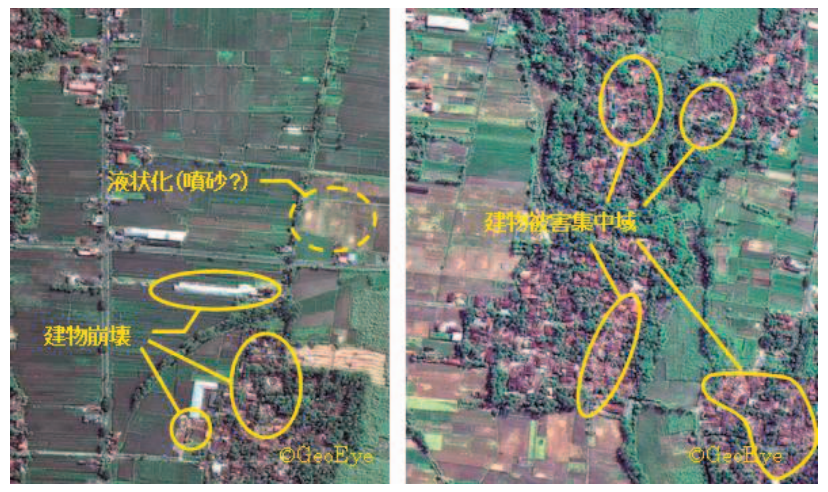

第 13 図. ジャワ島中部地震による建物被害の IKONOS 画像（い ずれも 2006 年 5 月 28 日撮影).
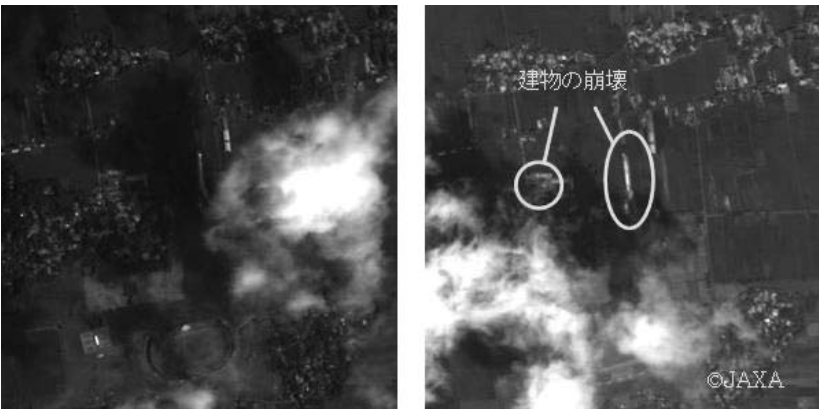

第 14 図. ジャワ島中部地震による建物被害の ALOS PRISM ステ レオ画像 (2006 年 6 月 12 日撮影). 左: 後方視 右: 前方視.

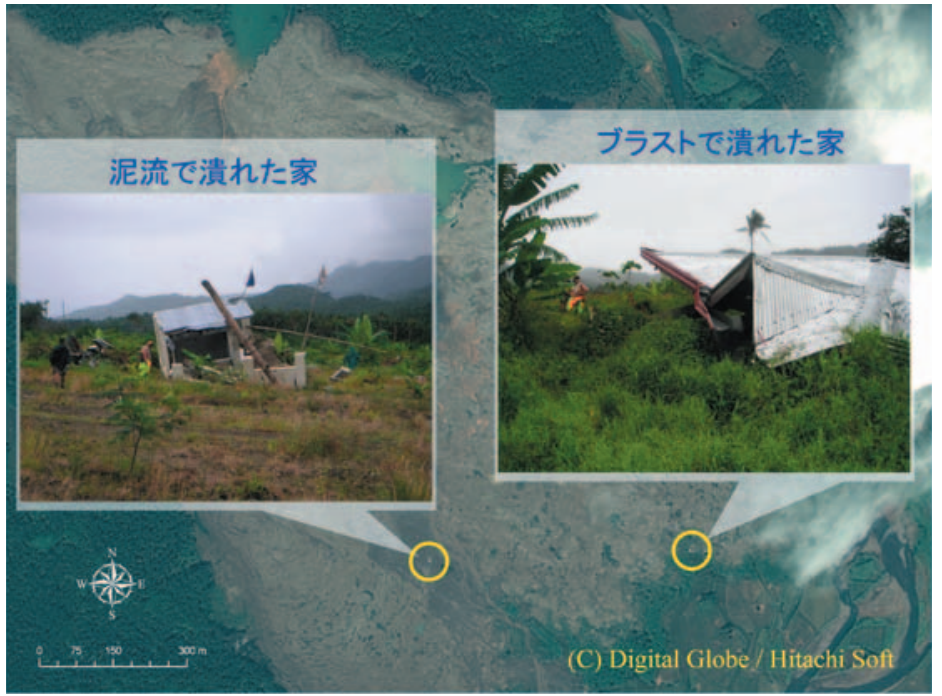

第 $\mathbf{1 5}$ 図.レイテ島地すべりによる建物被害の Quick Bird 画像（2006 年 4 月 16 日撮影)。現地写真は 2007 年 3 月 1 日撮影.

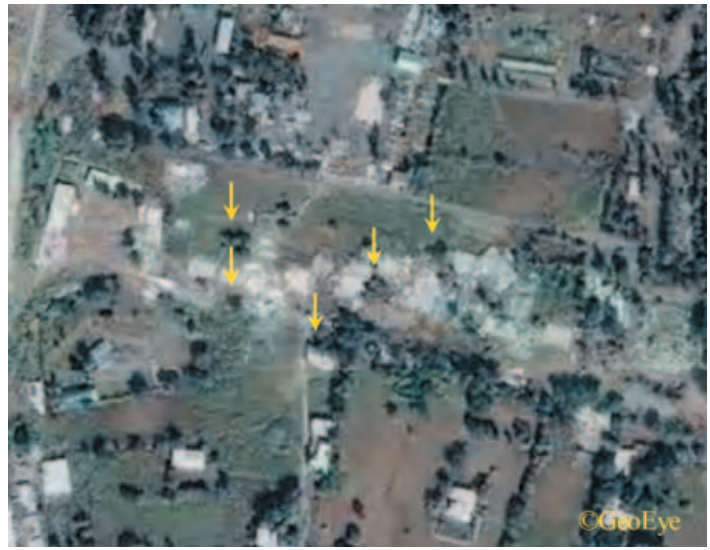

第 16 図. ムザファラバード北部の帯状に伸びた壊滅的 建物被害集中域の IKONOS 画像（2005 年 10 月 9 日撮 影). 矢印は場所特定のために使用した地物（樹木・建 物). 


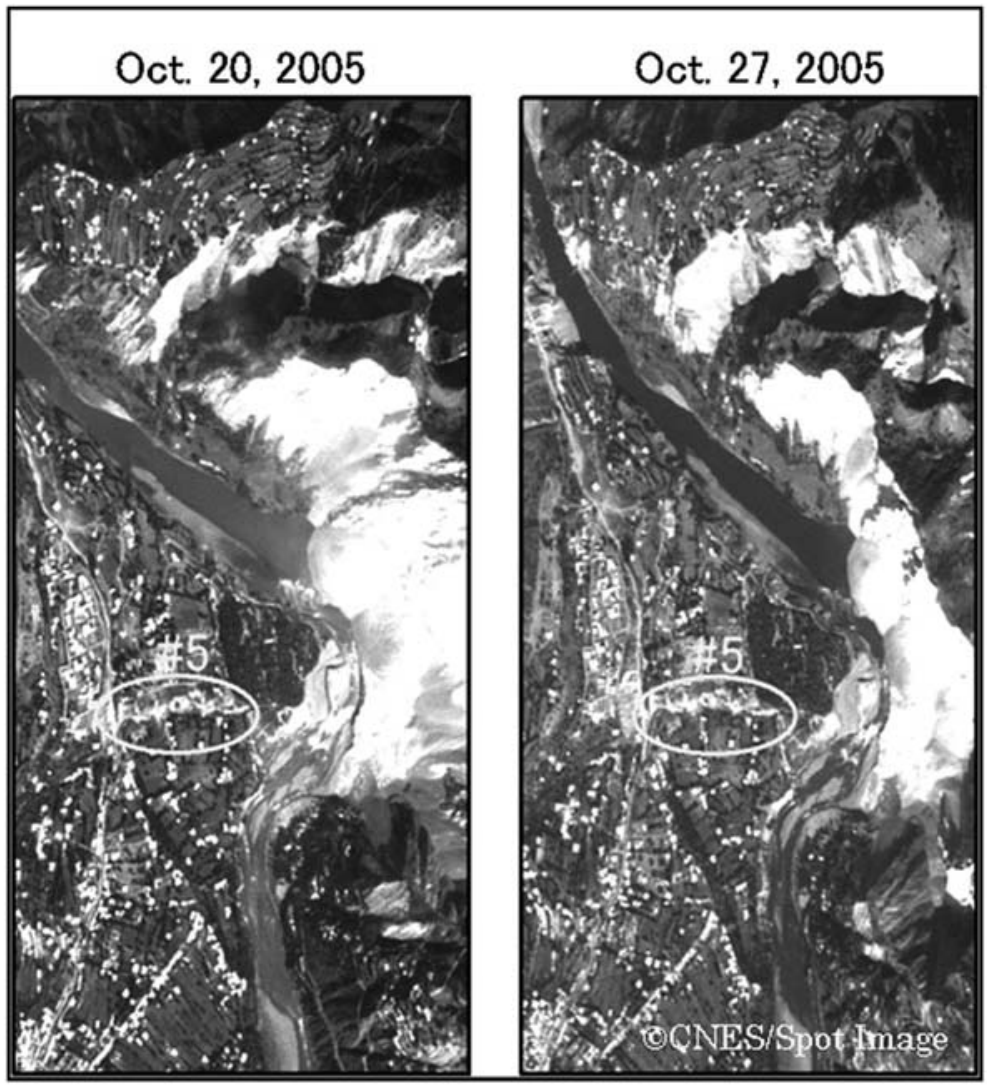

第 17 図. ムザファラバード北部の帯状の壊滅的建 物被害集中域の SPOT5 ステレオ画像（Sato et al., 2006より)。＃５は第16 図と同じ場所.
が建物一軒一軒の被害の判読も可能であった. IKONOS 画像 と QuickBird 画像については, web 上で同じ地域のものが 公開されていなかったため同じ場所での災害判読特性の比較 を行わなかつたので，明確な比較は出来ないが，QuickBird 画像の建物被害の判読特性の優位性を示していると考えられ る. 一方で，ムザファラバードに比べてバラコットは都市の 規模が小さく，建物 1 軒ごとの判読がバラコットの方が容易 であったこと, 今回の地震でのバラコットの街の建物倒壊率 が高く壊滅的な被害を受けていることが，建物倒壊の判読を 容易にしている可能性が考えられる. IKONOS 画像について も，ムザファラバード北部の郊外における壊滅的建物被害集 中域では建物 1 軒 1 軒の被害状況の判読が容易であつたこ とから (第 16 図)，もし IKONOS 画像でバラコットの建物 被害の判読を行えば, QuickBird 画像と比べても同程度の判 読精度が上がった可能性がある。

次に, $2.5 \mathrm{~m}$ クラス分解能のステレオ画像について考察す る. SPOT5 画像はステレオ画像ではあるが, 分解能が低い ため建物の倒壊状況までは判読が困難である. 第 11 図から は，建物等が集中している都市部が存在することは判読でき るが，画像を拡大しても建物 1 棟ごとの判読は困難であり, 建物被害の判読も不可能である. 小荒井ほか (2005, 2008a) は, SPOT5 の判読特性の評価をしていないが，分解能 5.8 $\mathrm{m}$ のインドの高分解能衛星 IRS 単画像の場合, 堅牢建物, プール，タンク等の大きな地物のみ判読可能であると評価し た. 都市部での判読特性を比較した場合, SPOT5 画像の判 読特性はほぼ IRS と同程度であると見なされる。一方，郊外
の住宅散在域であれば, SPOT5 画像, ALOS PRISM 画像共 に, 建物の存在は 1 軒 1 軒確認できると共に, 大きな建物で あれば 1 棟ごとの被害も判読可能であった (第 14 図).

その他の構造物被害判読については, IKONOS 単画像で橋 梁の破壊, 道路の不通箇所・損壊（土砂崩落による）, 河川 の濁りなどが判読され，郊外部では小規模な崩壊による道路 の不通箇所であっても, 道路が何かで覆われていれば判読は 可能であった. SPOT5 ステレオ画像については, 郊外部に おいては道路の存在は判読できたが, 道路の不通箇所・損壊 状況は, 大規模な斜面崩壊等によるもののみが判読できた. これは, 空中写真撮影が行えない状況下で災害直後の被災状 況（交通遮断状況）を把握するのに, 衛星画像判読が極めて 有効であることを示している。この結果は, IKONOS 画像, QuickBird 画像共に道路や道路付随施設については, 小規模 な道路付属施設を除いては判読が可能という小荒井ほか (2005, 2008a) の評価と調和的な結果である.

\section{3. 断層変位地形の判読特性についての考察}

断層変位地形については, 衛星画像のみで断層変位地形の 可能性の高い地形を判読することが出来た。 ただし， $1 \mathrm{~m}$ ク ラス分解能の単画像では実体視が出来ないため, 断層変位地 形の抽出は不可能であった．活断層近傍の帯状に繋がる壊滅 的建物被害集中域が判読できた。一方, $2.5 \mathrm{~m}$ 分解能のステ レオ画像では, 実体視により地表地震断層の可能性のある崖 地形の抽出は可能であったが，分解能は低かったため詳細な 判読は出来なかつた. 衛星画像や現地写真で確認できた帯状 に繋がる壊滅的建物被害集中域の存在は極めて特異であるこ 
第 3 表. 各地質災害種別毎の衛星画像による判読特性.

\begin{tabular}{|c|c|c|c|c|c|c|c|}
\hline \multicolumn{3}{|c|}{ 地質災害の種類 } & QuickBird & IKONOS & IKONOS & $\begin{array}{l}\text { ALOS } \\
\text { PRISM }\end{array}$ & SPOT5 \\
\hline & 単 & ステレオ & 単 & ステレオ & ステレオ \\
\hline \multirow[t]{7}{*}{ 斜面崩壊 } & \multicolumn{2}{|c|}{ 一般的斜面崩壊 } & 0 & (O) & 0 & 0 & 0 \\
\hline & & 0 & (O) & 0 & $(x)$ & $x$ \\
\hline & \multicolumn{2}{|c|}{ 切土部の小規模崩壊 } & $\mathrm{O}$ & (O) & $\mathrm{O}$ & $(x)$ & $x$ \\
\hline & \multicolumn{2}{|c|}{ 地すべり } & 0 & (O) & 0 & 0 & 0 \\
\hline & \multicolumn{2}{|l|}{ 亀裂 } & 0 & (O) & $\mathrm{O}$ & $(x)$ & $x$ \\
\hline & \multicolumn{2}{|c|}{ 流れ山地形 } & 0 & (O) & 0 & 0 & (O) \\
\hline & \multicolumn{2}{|c|}{ 崩壊域に残された岩塊 } & 0 & (O) & 0 & $x$ & $x$ \\
\hline \multirow[t]{14}{*}{ 建物被害 } & \multirow[t]{5}{*}{ 市街地 } & 建物の存在 & 0 & (O) & 0 & $x$ & $x$ \\
\hline & & 壊滅的被害域 & (-) & (O) & 0 & $\Delta$ & $\Delta$ \\
\hline & & 大きな建物の被害 & 0 & (O) & 0 & $x$ & $x$ \\
\hline & & 一般建物の全壊 & $\Delta$ & $(\Delta)$ & $x$ & $x$ & $x$ \\
\hline & & 一般建物の半壊 & $x$ & $(x)$ & $x$ & $x$ & $x$ \\
\hline & \multirow[t]{5}{*}{ 郊外 } & 建物の存在 & () & (O) & (a) & 0 & 0 \\
\hline & & 壊滅的被害域 & (a) & (๑) & 0 & 0 & 0 \\
\hline & & 大きな建物の被害 & 0 & (O) & 0 & 0 & $\Delta$ \\
\hline & & 一般建物の全壞 & 0 & (O) & $\Delta$ & $x$ & $x$ \\
\hline & & 一般建物の半壊 & $x$ & $(x)$ & $x$ & $x$ & $x$ \\
\hline & その他の & 橋梁の被害 & () & (O) & (2) & 0 & 0 \\
\hline & \multirow[t]{3}{*}{ 施設被害 } & 道路の不通(土砂) & (a) & (๑) & (a) & (O) & $\Delta$ \\
\hline & & 道路の不通(亀裂等) & 0 & (O) & 0 & $x$ & $x$ \\
\hline & & 道路の不通(大きな土砂災害) & (a) & (๑) & (a) & 0 & 0 \\
\hline \multirow{3}{*}{$\begin{array}{l}\text { 断層変位 } \\
\text { 地形 }\end{array}$} & \multirow{3}{*}{\multicolumn{2}{|c|}{$\begin{array}{l}\text { 断層崖·撓曲崖 } \\
\text { 建物被害密集域 } \\
\text { 河床の変化 }\end{array}$}} & $x$ & (๑) & $x$ & (O) & 0 \\
\hline & & & 0 & (O) & 0 & $(\Delta)$ & $\Delta$ \\
\hline & & & $\Delta$ & (O) & $\Delta$ & $(x)$ & $x$ \\
\hline
\end{tabular}

(): 判読良好; $\bigcirc$ : 判読可能 ; $\triangle$ : 条件により判読可能 (困難あり); $\times$ : 判読不可能

（）書きは，今回判読していないが，小荒井ほか（2005）などから推定して判断した結果

とから, $2.5 \mathrm{~m}$ クラス分解能のステレオ画像で確認できた崖 地形と, $1 \mathrm{~m}$ クラスの高分解能単画像で確認できる様々な特 異な現象（川の浅瀬の存在など）から判断される事象を組み 合わせることにより，断層変位地形の存在とその位置を大き な確度で認定することが出来た，ただし，最終的には，現地 確認が必要である. 現地調査前の断層変位地形抽出作業に当 たつて，ステレオ視可能な衛星画像が利用できれば極めて有 効である. また, 高分解能の衛星画像であれば実体視判読と いう空中写真とほぼ同様な手法での活用が可能である.

\section{高分解能光学衛星画像を用いた 災害状況把握手法についての考察}

\section{1. 地質災害判読のための高分解能光学衛星画像の利用法 と限界}

これまでに述べてきた各種高分解能光学衛星画像の災害状 況判読特性を，各災害種別に整理して一覧にまとめたものを 第 3 表に示す. $1 \mathrm{~m}$ クラスの商用高分解能衛星画像は高価で 容易に入手できなかったために, web 公開画像を使って検討 したのでステレオ画像が使えなかった. そのため, $1 \mathrm{~m}$ クラ ス分解能単画像 (カラー) と $2.5 \mathrm{~m}$ クラス分解能ステレオ画 像（白黒）とを比較した. なお, IKONOS のステレオ画像と
ALOS PRISM のステレオ画像の一部については, 今回の判 読カード作成の対象となっていない. そのため, 筆者らがこ れまでに地物の判読特性の整理を行ってきた研究成果（小荒 井ほか, 2005, 2008a など) を参考にして推定した結果を, 括 弧書きで表示してある. この表を見ると, 地質災害の種類に よらず, より高分解能な衛星画像の方が判読特性は良く, 単 画像よりもステレオ画像の判読特性が良い. しかし, 地質災 害の種類によって適用可能な衛星画像の分解能等が違ってく るので, 災害時の災害状況把握における最適な高分解能光学 衛星画像の利用法とその限界について考察する.

基本的には高分解能の衛星画像の方が判読特性は良いが, 高分解能ほど観測幅が狭くなるため, 判読に必要な衛星画像 のシーン数が多くなり, 現実的ではない，そのため，まずは 広域を $2.5 \mathrm{~m}$ クラス分解能のステレオ画像で判読して災害状 況の概要を知り, 被害集中域等をピンポイントでより高分解 能の $1 \mathrm{~m}$ クラス分解能衛星画像で判読することが望ましい.

地震等の地質災害が発生した場合, 発災直後の緊急対応時 には, 大規模被害発生域を早期に特定・把握し, 人命に係る 避難・救出活動が適切に行われるよう, その情報を災害対策 本部等に早急に提供することが肝要である. 特に, 土砂災害 発生場所, 建物壊滅的被害集中域, 交通インフラ状態, 液状 
第 4 表. 災害状況判読の視点で見た各衛星センサの特徵.

\begin{tabular}{|c|c|c|c|c|}
\hline 機能 & QuickBird & IKONOS & ALOS PRISM & SPOT5 \\
\hline 高分解能 & (2) & $\mathrm{O}$ & $\triangle$ & $\triangle$ \\
\hline ステレオ撮影 & $\Delta$ & $\triangle$ & (2) & $\mathrm{O}$ \\
\hline ポインテイング機能(撮影間隔) & 0 & $\mathrm{O}$ & $x$ & $\mathrm{O}$ \\
\hline 観測幅 & $\Delta$ & $\triangle$ & 0 & $\mathrm{O}$ \\
\hline
\end{tabular}

(○) : 非常に良好 ; $\bigcirc$ : 良好 ; $\triangle$ : やや問題有 ; $\times$ : 不可能

化に関する情報が重要である. $2.5 \mathrm{~m}$ 分解能の衛星画像の目 視判読により, 大規模な地すべり・土砂災害が多数発生した 地域の状況把握, 河道閉塞の抽出等が可能であり, 幹線道路 の通行不能状態については, 土砂崩壊によるものや橋梁落下 によるものは抽出可能である. 一方, 市街地における建物被 害の判読については $1 \mathrm{~m}$ クラスの分解能が必要で, 出来れば ステレオ画像が望ましい。 しかし, 建物壊滅的被害集中域に ついては, $2.5 \mathrm{~m}$ 分解能衛星画像でも抽出可能な事例が多い ことから, 応急対応時には人命に係る避難・救出活動を適切 に行う視点から，建物被害に関しては壊滅的被害集中域に特 化して抽出作業を行つた方が良い.

発災直後の応急対応時以降，被災施設の特定，地形変動の 抽出，一般的災害状況の把握等が必要になってくる. この段 階になって, $1 \mathrm{~m}$ クラスの分解能の衛星画像の目視判読によ る情報抽出が必要になってくる，斜面崩壊については，単画 像や $2.5 \mathrm{~m}$ 分解能でも判読は可能であるが，単画像では斜面 崩壊の形状等を正確に捉えることは出来ず，小規模な崩壊や 浅い表層崩壊, クラック等の判読は $2.5 \mathrm{~m}$ 分解能では困難も しくは不可能であり, $1 \mathrm{~m}$ 分解能が必要である. 一方, 建物 被害については $1 \mathrm{~m}$ 分解能であっても限界があり, 市街地 では大きな建物の被害であれば判読は可能であるが，一般建 物の全壊・半壊は判読が困難もしくは不可能である。郊外で あっても，一般建物の全壊は単画像では困難であり，一般建 物の半壊の場合は IKONOS のステレオ画像や $0.6 \mathrm{~m}$ 分解能 のQuickBird 画像であっても判読は不可能である. 断層変 位地形については, 地形の上下変化等が判読の鍵になるので, ステレオ画像でないと判読が困難である. $2.5 \mathrm{~m}$ クラス分解 能のステレオ画像による崖地形の抽出と, $1 \mathrm{~m}$ クラス分解能 の単画像による建物被害密集域抽出の組み合わせで, 初めて 判読が可能である. なお, 衛星画像でも画像の端での倒れ込 みがあり, オフナディア角が大きい時には急峻で起伏量が大 きな山岳地において判読の障害となることが想定される。 今 回の研究で使用された画像と地形条件とを照らし合わせてみ ると，建物被害の判読については都市部の平らな部分であつ たために特段の障害はなかつた。 また，地表地震断層の判読 についても山地内の平野部での実体視判読が主であつたた め，特段の支障は無かつた，斜面崩壊の判読については，山 地部での判読であるために多少の障害が考えられるが，今回 はステレオ画像を実体視判読し，それをステレオ画像から作 成したオルソ画像に移写する形で斜面崩壊のポリゴンデー夕
を作成したために，判読上の困難は無かった. 唯一, レイテ 地すべりの高分解能画像は， 単画像でオフナディア角が大き かったため, 崩壊部の判読では立体感が無くのつぺりしてし まい, やや判読が困難であると共に, 判読したものを他の空 間情報と組み合わせて使うことが不可能であった. 山地部で の災害状況の判読には, 直下視の画像かステレオ画像を使う ようにするのが望ましい

\section{2. 各種衛星センサの評価と次世代地質災害監視衛星の満 たすべき要件についての考察}

災害状況判読という視点で総合的に各センサの特性を評価 して整理したものを第 4 表に示す。災害対応という視点でセ ンサの特性を考えたとき, 高分解能, 広い観測幅, 高頻度撮 影，実体視可能の 4 つが大きな特性になる。これらの特性 は，相互に相殺する，例えば，同じレンズ特性であれば高分 解能になるほど衛星高度を下げることになるので観測幅が狭 くなる，もしくは，高分解能だとデー夕量が大きくなるため， それが制約条件となって観測幅を広く出来ない可能性があ る. 一方，ステレオセンサとしての特性を高度なものにする には，ポインティング機能を持たせずにセンサを固定するこ とになるので (ALOS PRISM がその代表例)，撮影頻度は極 端に低くなる。

高分解能については, $2.5 \mathrm{~m}$ クラス分解能の衛星画像より も $1 \mathrm{~m}$ クラス分解能の衛星画像の災害判読特性が良いので, $1 \mathrm{~m}$ クラス分解能センサの方を $2.5 \mathrm{~m}$ クラス分解能センサよ りも高く評価した，QuickBird についてはIKONOSよりも 災害判読特性が良かつたので，より高く評価した。観測幅に ついては, $1 \mathrm{~m}$ クラス分解能衛星が $11 \sim 16 \mathrm{~km}, 2.5 \mathrm{~m}$ ク ラス分解能衛星が約 $60 \sim 70 \mathrm{~km}$ なので, $2.5 \mathrm{~m}$ クラス分解 能衛星センサの方を高く評価した. ステレオ撮影に関しては どのセンサも可能ではあるが, 商用高分解能衛星では実際に ステレオ撮影のアーカイブが余りなされていないので，その 点は多少低く評価した。一方, ALOS PRISM については, ポインティングによる実体視ではなく三方向センサによる実 体視であるため，確実に良好なステレオ画像が撮影できるこ とからより高く評価した．ポインティング機能（撮影間隔） については, ALOS PRISM センサについてはポインティン グ機能を有せず撮影間隔が 46 日であることは，災害状況把 握目的には不利であることから低く評価した。

このようにして作成した第 4 表を見ると, $1 \mathrm{~m}$ クラス分解 能衛星センサと $2.5 \mathrm{~m}$ クラス分解能衛星センサとは, 災害状 
況把握に必要な特性を相互補完的に有していることが判る. 観測幅とステレオ撮影で優位な特性を持つ $2.5 \mathrm{~m}$ クラス分解 能衛星センサ（特にSPOT5）で広域をステレオ撮影して概 況を把握し，高分解能で優位な特性を持つ $1 \mathrm{~m}$ クラス分解能 センサで災害状況の詳細を把握するという相互補完方法であ る. ALOS PRISM については，撮影間隔の面で災害状況把 握での利活用に不利であり, 活躍する場は少ないと想定され るが，タイミング良く災害状況を撮影された場合には，ステ レオ撮影の面で他のセンサと比べて優位な特性を有してお り，災害状況把握の面で有意義な情報を提供することが可能 である。

今後, 災害監視に特化した高分解能光学衛星が打ち上げら れる可能性もあり, 地質災害の状況把握に必要な衛星センサ の要件について，4つの特性の視点から考察する. 災害状況 を的確に把握するためには， $1 \mathrm{~m}$ クラスの高分解能でのステ レオ撮影が不可欠である. 安定したステレオ撮影を行うため には，ポインティング機能によるステレオ撮影ではなく, ALOS PRISM センサのように 2 方向以上のセンサ（例えば, 直下視と後方視）による同一軌道内でのステレオ撮影が, 常 に出来るセンサ設計が望ましい. むろん，高頻度の撮影をす るためには，ポインティング機能を有していることも必要な 条件である. 観測幅については, M7 クラスの活断層起因の 内陸地震の場合（例えば, 1995 年兵庫県南部地震など）の被 害域を 1 シーンでカバーできることを考えると，震央周辺で $50 \mathrm{~km}$ 四方程度の観測幅が必要である。観測頻度に関して は，緊急対応時の災害状況把握の二ーズを考えると，発災後 3 時間以内の観測が必要であるが，ポインティング機能を有 していても 1 機体制では困難で，数機体制が必要になると考 えられる。

次世代の災害監視用の高分解能光学衛星センサとしては, 分解能がパンクロマティックで $1 \mathrm{~m}$ ，マルチスペクトルで 4 $\mathrm{m}$ ，観測幅 $50 \mathrm{~km}$ 以上，2 方向以上のセンサを有して同一軌 道内のステレオ撮影が常時可能で, ポインティング機能を有 した衛星センサの数機運用による 3 時間毎の撮影間隔という 要件が必要と考える.

\section{ま と め}

開発途上国において発生したパキスタン北部地震，ジャワ 島中部地震, レイテ島地すべりの 3 つの大規模な地質災害に 関して, 高分解能光学衛星画像を活用して, 斜面崩壊, 建物 被害, 断層変位地形等の災害状況について判読を行つた. 様々な分解能の高分解能衛星画像を使用して判読を行い, 同 一の災害事象についての判読結果を判読事例カードにとりま とめ, それぞれの衛星画像の災害判読特性を比較検証してと りまとめた.

その結果, $2.5 \mathrm{~m}$ 分解能の衛星画像では斜面崩壊の判読は 可能であったが, 表層崩壊や亀裂などの判読は $1 \mathrm{~m}$ 分解能 程度の衛星画像が必要であることが分かつた。建物被害等の 判読は $2.5 \mathrm{~m}$ 分解能では不可能で, $1 \mathrm{~m}$ 分解能が必要である が，単画像では実体視ができないため都市部での網羅的な被 害のマッピングは困難である，壊滅的被害の集中域では，単
画像でも判読は可能である. また, QuickBird 画像の方が, IKONOS より分解能が細かい分, 建物被害の判読には有利で あつた. 断層変位地形の判読については, $1 \mathrm{~m}$ 分解能でも単 画像では高低感が捉えられないため困難である。ただし，1 $\mathrm{m}$ 分解能で建物壊滅的被害集中域が判読できたので, $2.5 \mathrm{~m}$ 分解能のステレオ画像の判読と組夕合わせて, 地表地震断層 の可能性のある地形を抽出でき, 活断層研究者の現地調査に より確認ができた. $1 \mathrm{~m}$ クラス単画像と $2.5 \mathrm{~m}$ クラスステレ 才画像とを比較した結果, 高分解能の方が判読特性は一般的 には優れているが，災害判読における実体視判読の有用性も 示すことができた.

以上の結果を基に, 開発途上国を対象に高分解能光学衛星 画像を使用した大規模地質災害の状況把握手法を整理した。 初期段階で広域を $2.5 \mathrm{~m}$ クラス分解能のステレオ画像で判読 して災害状況の概要を知り, 被害集中域等をピンポイントで より高分解能の $1 \mathrm{~m}$ クラス分解能衛星画像で判読することが 必要である. 特に, 発災直後の緊急対応時には, 土砂災害の 発生箇所の把握と建物壊滅的被害集中域の把握が極めて重要 であり, $2.5 \mathrm{~m}$ クラス分解能のステレオ画像による広域的な 災害概要把握が重要である. また, 各衛星画像を災害状況把 握へ利活用する観点から, 高分解能, 広い観測幅, 高頻度撮 影, 実体視可能の 4 つの特性の視点で現行の衛星センサを評 価して整理した。 その結果, 今後の災害監視に特化した高分 解能光学衛星の打ち上げを視野に入れた場合, 分解能 $1 \mathrm{~m}$, 観測幅 $50 \mathrm{~km}$ 以上, 同一軌道内のステレオ撮影が常時可能 で，ポインティング機能を有するという衛星センサが必要で ある。

\section{謝 辞}

断層変位地形の判読に関しては, 日本地理学会災害対応委 員会 ML での議論が参考になつた。 また, ALOS PRISM 画 像については, 宇宙航空研究開発機構 (JAXA) からの提供 を受けると共に, 判読画像作成にあっては国土地理院地理地 殼活動研究センタ一地理情報解析研究室の神谷泉主任研究官 にお世話になった。判読事例集の作成, および図表の作成に あたつては同室の村上弘明氏にお世話になった。 また, web に公開されている高分解能衛星画像の本論文での使用につい ては, 日本スペースイメージング社, 日立ソフトウェアエン ジニアリング (株) の了解を得た. また, 匿名の査読者 2 名 の方と編集企画委員の能美洋介氏には，原稿を大幅に改善す る貴重な御意見を頂いた。 これらの方々に感謝する.

\section{文献}

衛星リモートセンシング推進委員会空間データワーキンググループ, 2002, 高分解能衛星画像による地物の判読可能性. 171p.

Fujiwara, S., Tobita, M., Sato, H.P., Ozawa, S., Une, H., Koarai, M., Nakai, H., Fujiwara, M., Yarai, H., Nishimura T. and Hayashi, F., 2006, Satellite data gives snapshot of the 2005 Pakistan earthquake. EOS, trans. $A G U ., 87,73-77$.

Geological Survey of Pakistan, 1993, Geological map of Pakistan 1: $1,000,000$.

Irwan, M. ・安藤雅孝・奥田 隆・木股文昭, 2006, 2006 年 5 月 27 日ジ ヨグジャ地震の緊急地震調査. 日本地震学会ニュースレター, 18- 
3,11-13.

小荒井 衛 - 飯田 洋 - 都留宏介・樋野隆司・峰島貞治 - 洲濱智 幸・䔖山邦幸, 2005, 各種高分解能衛星画像地物判読可能性の検 討. 日本写真測量学会平成 17 年度秋季学術講演会発表論文集, 21-24.

小荒井 衛 - 飯田 洋 - 都留宏介 - 樋野隆司 - 峰島貞治 - 洲濱智 幸・䔖山邦幸, 2008a, 高分解能衛星画像の大縮尺地形図作成のた めの地物判読特性についての体系的整理. 地図, 46-3, 13-28.

小荒井 衛 - 飯田 洋 ・渡辺信之・吉永新一郎・都留宏介・樋野隆 司・井上 潮 - 洲濱智幸 - 中村 忠, 2002 , 高分解能衛星画像 （IKONOS 画像）による地物の判読可能性について。 日本写真測 量学会平成 14 年度学術講演会発表論文集, 169-174.

小荒井 衛 - 佐藤 浩・新井場公徳・小山内信智・伊藤英之, 2008b, リモートセンシングで捉えたレイテ島岩首なだれの地形的特徵. 日本地すべり学会誌, 45-2, 14-25.

小荒井 衛 - 佐藤 浩 ・ 神谷 泉・新井場公徳 - 小山内信智 - 伊藤 英之, 2007, レイテ島地すべりの地形的特徵. 国土地理院時報, 113, 111-120.

Koarai, M., Sato, H. P., Une, H. and Kamiya, I., 2006, Interpretation of high-resolution satellite imageries to detect the landform changes and disaster damages: Case study of the northern Pakistan earthquake. Asia-Pacific Remote Sensing Proceedings. 6412-6420.

Kumahara,Y. and Nakata,T., 2006, Active faults in the Epicentral Area of the 2005 Pakistan Earthquake. Research Center for Regional Geography, Hiroshima University, 54p.

熊原康博・中田 高, 2007, CORONA 偵察衛星写真の判読に基づく 2005 年パキスタン地震の起震断層の認定. E-journal GEO, 2-2, $72-85$.
向山 栄, 2004, 平成 16 年新潟県中越地震の被災状況を IKONOS 衛星 画像で見る,写真測量とリモートセンシング．43-6, 2-3.

向山 栄, 2006, 地震災害発生直後に期待する災害情報の特性と IKONOS 衛星画像の利用,先端測量技術。 $89 \cdot 90,108-113$.

佐藤 浩, 2007, 2005 年パキスタン北部地震による斜面崩壊の分布. E-journal GEO, 2-2, 104-120.

Sato, H. P., Hasegawa, H., Fujiwara, S., Tobita, T., Koarai, M., Une, H. and Iwahashi, J., 2007, Interpretation of landslide distribution triggered by the 2005 Northern Pakistan earthquake using SPOT5 imagery. Landslide, 4, 113-122.

Sato, H. P., Koarai, M., Une, H., Hasegawa, H., Iwahashi, J., Kamiya, I. and Ishitsuka, Y., 2006, Interpretation of Landslide Distribution triggered by the Northern Pakistan Earthquake on 8 October 2005 using 2.5mresolution SPOT5 Stereo-imagery. Extended abstract of international conference on earthquake in Pakistan, 94-98. Geological Survey of Pakistan.

佐藤 浩・宇根 寛・小荒井 衛, 2005 ,パキスタン北部地震に対する イコノス画像の判読と解釈. 写真測量とリモートセンシング, 446, 2-3.

諏訪 浩, 2006,フィリピン・レイテ島で 2006 年 2 月 17 日に起きた 地すべり災害. 25-1, 83-87.

消防研究センター・国土技術政策総合研究所・国土地理院, 2007,フィ リピン・レイテ島地すべり災害における救援活動の実態と応援技 術の性能調査報告書. $44 \mathrm{p}$.

上野宏共・地下まゆみ, 2006, フィリピン共和国レイテ島地すべりと地 質. 地質ニュース, no.622, 41-48.

宇根 寛・熊木洋太, 2007 , パキスタン北部地震による地表断層変位の “リモートセンシング”. E-journal GEO, 2-2, 86-94.

(要 旨)

小荒井 衛·佐藤 浩·宇根 寛・天野一男, 2008 , 各種光学高分解能衛星画像による地質災 害の判読一判読特性の視点から見た各種画像の比較検証一．地質雑，114，632-647. (Koarai, M., Sato, H.P., Une, H. and Amano, K., 2008, Interpretation of geological hazard using high-resolution optical satellite imagery: Comparison of interpretation characteristics of satellite images. Jour. Geol. Soc. Japan, 114, 632-647.)

パキスタン北部地震，ジャワ島中部地震，レイテ島地すべり等の大規模地質災害につい て, 光学系高分解能衛星画像により被害状況と地形的な特性把握を試みた。 また, 高分解 能衛星画像の災害判読特性を判読カードに整理しカタログ化を進め比較検証した. $2.5 \mathrm{~m}$ 分解能の衛星画像で斜面崩壊の判読は可能だが，小規模な表層崩壊や亀裂などの判読は 1 $\mathrm{m}$ 以上の分解能が必要であった。建物被害等の判読には $1 \mathrm{~m}$ 分解能が必要である. しかし ながら単画像では実体視ができないため, $1 \mathrm{~m}$ 分解能でも単画像では都市部での網羅的な 建物被害のマッピングは困難である. 断層変位地形の判読については, $1 \mathrm{~m}$ 分解能でも単 画像では高低感が捉えられないため困難である。ただし，建物被害集中域が判読できたの で, $2.5 \mathrm{~m}$ 分解能のステレオ画像の判読と組み合わせて, 地表地震断層の可能性のある地 形を抽出できた，各衛星画像を比較した結果，高分解能の方が判読特性は一般的には優れ ているが，災害判読における実体視判読の有用性も示すことができた．本研究の考察を通 して, 高分解能光学衛星画像を使用した大規模地質災害の状況把握手法を提案した. 